\title{
A Brief Review of Poly (Butylene Succinate) (PBS) and Its Main Copolymers: Synthesis, Blends, Composites, Biodegradability, and Applications
}

\author{
Laura Aliotta $^{1,2} \mathbb{D}$, Maurizia Seggiani ${ }^{1,2} \mathbb{D}$, Andrea Lazzeri ${ }^{1,2} \mathbb{D}$, Vito Gigante ${ }^{1,2, *(\mathbb{D})}$ and Patrizia Cinelli ${ }^{1,2, * \mathbb{D}}$ \\ 1 Department of Civil and Industrial Engineering, University of Pisa, 56122 Pisa, Italy; \\ laura.aliotta@dici.unipi.it (L.A.); maurizia.seggiani@unipi.it (M.S.); andrea.lazzeri@unipi.it (A.L.) \\ 2 Consorzio Interuniversitario Nazionale per la Scienza e Tecnologia dei Materiali (INSTM), 50121 Florence, Italy \\ * Correspondence: vito.gigante@dici.unipi.it (V.G.); patrizia.cinelli@unipi.it (P.C.)
}

\section{check for}

updates

Citation: Aliotta, L.; Seggiani, M.;

Lazzeri, A.; Gigante, V.; Cinelli, P. A

Brief Review of Poly (Butylene

Succinate) (PBS) and Its Main

Copolymers: Synthesis, Blends,

Composites, Biodegradability, and

Applications. Polymers 2022, 14, 844

https://doi.org/10.3390/

polym14040844

Academic Editor: Asterios (Stergios) Pispas

Received: 29 January 2022

Accepted: 17 February 2022

Published: 21 February 2022

Publisher's Note: MDPI stays neutral with regard to jurisdictional claims in published maps and institutional affiliations.

Copyright: (C) 2022 by the authors. Licensee MDPI, Basel, Switzerland. This article is an open access article distributed under the terms and conditions of the Creative Commons Attribution (CC BY) license (https:// creativecommons.org/licenses/by/ $4.0 /)$.

\begin{abstract}
PBS, an acronym for poly (butylene succinate), is an aliphatic polyester that is attracting increasing attention due to the possibility of bio-based production, as well as its balanced properties, enhanced processability, and excellent biodegradability. This brief review has the aim to provide the status concerning the synthesis, production, thermal, morphological and mechanical properties underlying biodegradation ability, and major applications of PBS and its principal copolymers.
\end{abstract}

Keywords: PBS; synthesis; biodegradability; binary blends

\section{Introduction}

Over the past century, polymeric materials have become one of the most attractive areas of materials science due to their low cost, reproducibility, ease of machining, and assorted mechanical properties [1], but since the late 1990s, society has encountered the problem of global warming and fossil fuel depletion. Annually in Europe, approximately 25.8 million tons of post-consumer plastic wastes are generated and about $40 \%$ are destined for incineration [2]. In 2018, the annual growth rate of $8.4 \%$ of plastic production equated to about 360 million tons. This is estimated to reach 500 million tons in 2025 and from this total production, $60 \%$ will enter the environment as plastic waste [3].

In order to overcome these above-mentioned complications, the decision to use, where possible, sustainable resources instead of fossil-based resources has been taken into consideration in order to decrease environmental issues [4]. The serious problem of environmental pollution produced by the widespread use of plastics incentivized the investigation on bio-based and biodegradable polymers (bioplastics) [5].

Bioplastics are currently used in a high number of application fields, e.g., biomedical devices such as wound dressings, bio-resorbable implants, and drug carriage systems. Indeed, in these applications it is possible to justify the high cost of the raw materials. However, their use in packaging or agriculture remains restricted due to economic reasons and problems with environmental issues [6].

Among of all bioplastics that are bio-based, which means that they are produced from natural resources, it is possible to distinguish two categories: biodegradable and nonbiodegradable [7]. The diversity of biodegradable bioplastics can be found in the variation of biodegradation rates and routes. However, similar to oil-based plastics, biodegradable bio-based plastics can also be recycled or incinerated. Nevertheless, nowadays they are not recycled because in the current recycling systems they are seen as contaminants. Biodegradable plastics can also microbially degrade, allowing an alternative end-of-life management and facilitating the development of a circular economy $[8,9]$.

Poly(lactic) acid (PLA), poly(hydroxy alkanoates) (PHAs), succinate-derived polymers, and other bioplastics were commercialized and extensively studied [10-15] because they 
could solve waste issues in several application fields (involving marine and construction items) [16].

Taking into account the succinate-derived polymers, some important synthetic biodegradable polyesters are poly (ethylene succinate) (PES), poly (propylene succinate) (PPS), poly (butylene adipate) (PBA), and poly (butylene succinate) (PBS) and its well-known copolymer poly butylene succinate-co-adipate (PBSA) [17]. They are typically obtained from the reaction between a diacid or acid anhydride and diols with the elimination of water. These aliphatic polyesters are not considered bio-based since they are produced with conventional fossil resources such as petroleum oil and natural gas. However, at present, they can also be produced using monomers from renewable resources [18]. Their development is expanding; hence, monitoring, through this review, the state of the art, the synthesis, and the biodegradation capability of PBS and PBSA blends, composites, and application cannot be neglected.

In fact, for many years, PBS and PBSA were produced from petrochemical sources by Showa Highpolymer (Shanghai, China), but the important novelty was the production of PBS by renewable resources, for example, from sugarcane, cassava, and corn. This new trend has been underway over the last ten years, making PBS a valid sustainable, bio-based, and biodegradable plastic alternative. Compared with other biopolymers, PBS shows improved eco-efficiency subject to end-of-life (EOL) routes [19]. Massive efforts have been dedicated to the investigation and synthesis of PBS and its copolymers starting from 1993 for the production of mulching films, compostable bags, nonwoven sheets, and garments [20], and nowadays, via copolymerization with other dicarboxylic acids or diols, the properties of PBS can be varied in a wide range [21]. In the literature, the copolymer of succinic acid and other dicarboxylic acids such as poly(butylene succinate-co-butylene terephthalic acid) [22] and poly(butylene succinate-co-butylene furandicarboxylate) [23], have been investigated.

From the point of view of physical properties, that will be shown in detail in the next paragraph, PBS is a white crystalline thermoplastic polymer with a density of $1.25 \mathrm{~g} / \mathrm{cm}^{3}$, a melting point $\left(\mathrm{T}_{\mathrm{m}}\right)$ in the range of $90-120^{\circ} \mathrm{C}$, and a low glass transition temperature $\left(\mathrm{T}_{\mathrm{g}}\right)$ of about -45 to $-10^{\circ} \mathrm{C}$ [24]. It presents good mechanical properties and excellent processability in textile filaments, injection molds, and extruded and blown products [25]. In fact, PBS also has a wide temperature range, namely, it can be worked similarly to polyolefins in the range of $160^{\circ} \mathrm{C}$ to $200^{\circ} \mathrm{C}$ [26]. In terms of brittleness, PBS is more rigid than PBSA but slightly ductile [27]. PBS also has good thermal stability [28]. Moreover, its high flexibility guarantees its use in many application involving film production [21,29-32]. New possible applications for PBS have been investigated in the last years such as the growth of novel materials for ecological agricultural purposes; in fact, mulched nonwoven materials and pots can be valid alternatives to polypropylene ones [33-35]. The lack of accessibility is a limitation of PBS, which used to obstruct its extension. To boost its properties for different purposes, PBS can be modified [36].

Nowadays, PBS can be found on the market thanks to Mitsubishi Chemicals that built a plant with an annual capacity of 3000 tons in 2003 and launched to the market a PBS named GS Pla (Green and Sustainable Plastic) [37], but it can also be blended with PLA: for example, a commercial PLA/PBS blend used for packaging is produced by NatureWorks LLC [38,39], and one plasticized with isosorbide has been proposed as a novel solution for food service ware [40]. A highly-bio-based and compostable PLA/PBS product, with the trade name BioFlex ${ }^{\circledR}$ S 5630, was developed by FKuR Kunststoff GmbH and Fraunhofer UMSICHT; this commercial product is tailored for thermoforming, calendaring, and injection molding [41].

\section{Synthesis and Production}

Prevalently, PBS is produced by succinic acid (SA) and 1,4-butanediol (BDO) polycondensation (Figure 1). PBS can be produced both by monomers derived from petro-based sources and by bacterial fermentation route [42]. BioAmber Inc. started the commercializa- 
tion of bio-based succinic acid in 2010. Novamont S.p.A. began producing 1,4-butanediol from renewable resources in 2016 [38].

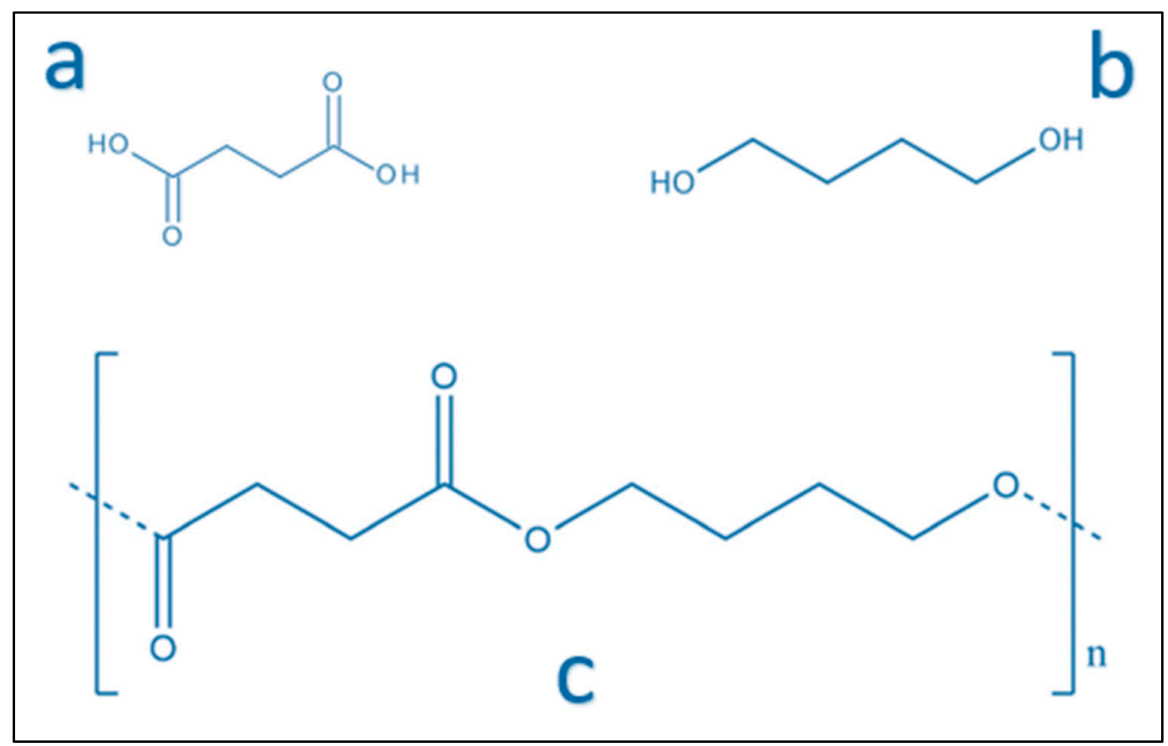

Figure 1. Chemical structure of (a) succinate acid, (b) 1,4-butanediol, and (c) poly(butylene succinate) (PBS).

The synthesis can be separated into two steps: the first stage is the esterification of succinic acid and BDO to obtain oligomers. The second step is the polycondensation of oligomers to achieve high-molecular-weight PBS. The flow chart of PBS production is shown in the figure below (Figure 2) [43].

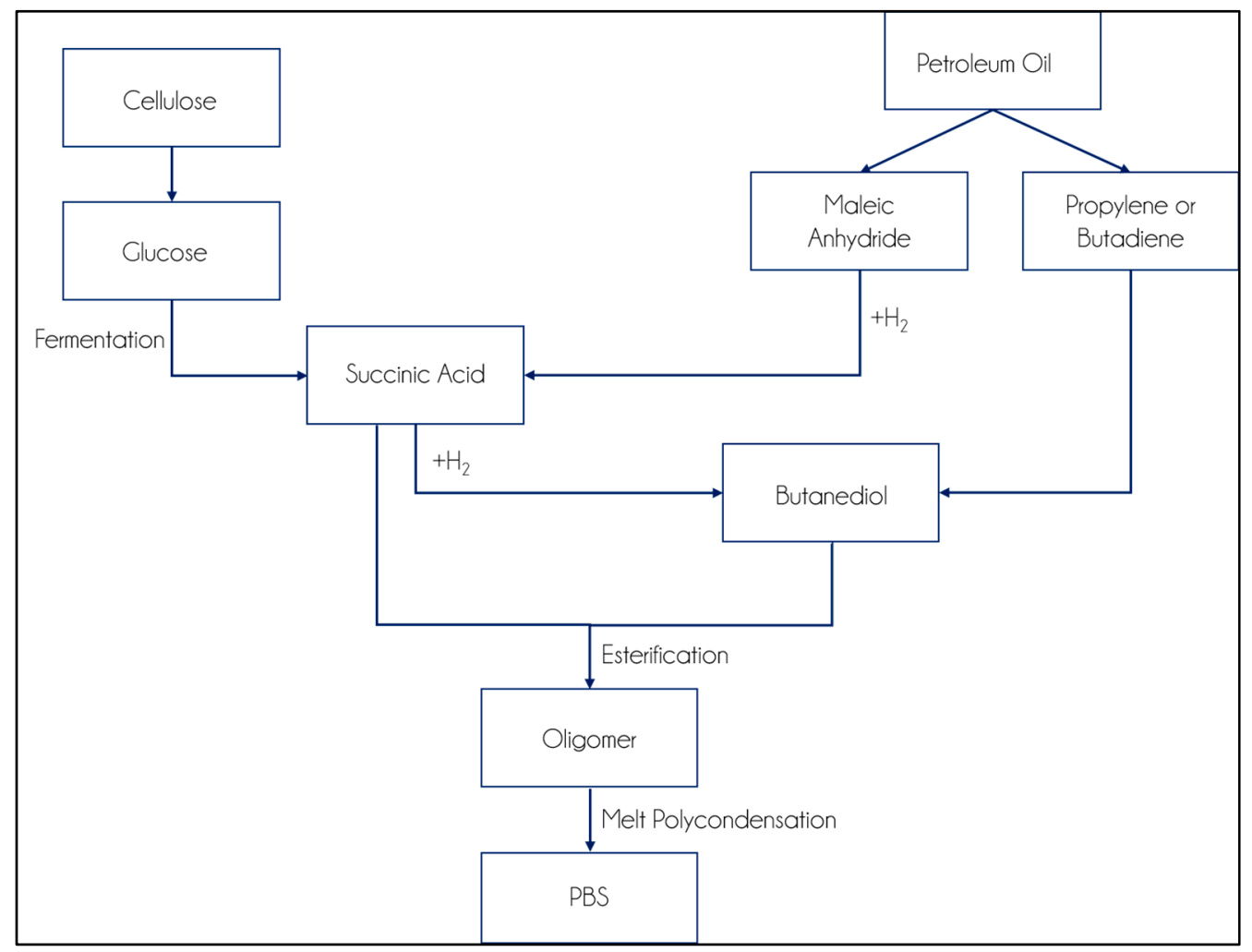

Figure 2. Flow Chart of PBS synthesis (Adapted with permission from Reference [43]. Copyright 2010 Wiley). 
The synthesis usually takes place in a reactor furnished with a mechanical stirrer, an inlet for the inert gas (usually nitrogen, to avoid oxidation during the esterification step), and a distillation column [44]. This reactor is heated to $160-190{ }^{\circ} \mathrm{C}$ to start esterification under stirring and eventually under a controlled atmosphere. When no more water (or alcohol) is distilled out under normal pressure, polycondensation is further carried out at high temperatures $\left(220-240{ }^{\circ} \mathrm{C}\right)$ [45].

However, high molecular weights are required to obtain polymeric materials with good mechanical properties; nevertheless, the synthesis of high-molecular-weight aliphatic polyesters by conventional polycondensation is difficult due to the simultaneous competing reactions of condensation and degradation [46]. For this reason, to obtain polyesters with useful mechanical properties, it is necessary to introduce side chains with aromatic units and chain extenders to increase the molecular weight or, more frequently, catalysts to accelerate the kinetics [47]. Many articles suggested the use of a diisocyanate such as 1,6-hexamethylene diisocyanate (HDI) as chain-extending agent. Ideally, the chain extender molecule has two functional groups that can react with the terminal $-\mathrm{OH}$ or $-\mathrm{COOH}$ of PBS and a couple of polymer chains. However, the disadvantage is that the chain extender integration will reduce biodegradability [48]. Catalysts, especially titanium compounds, are usually devoted to the synthesis of PBS [49].

It is important to underline that by changing the composition of the monomer, the mechanical properties can be tailored to the desired application [50].

To the best of the authors' knowledge, benzoic acid production methods can currently be divided into two groups: petro-based methods and fermentation ones. Various industrial processes for the production of petroleum-based SA have been carried out in the last century, e.g., catalytic hydrogenation of maleic acid and electrochemical synthesis of maleic anhydride in a bipolar membrane cell or in a membrane-free cell [43].

On the other hand, production by fermentation is because benzoic acid is the preferable intermediate in the metabolism of anaerobic and pro-fermentative microorganisms. Several studies have shown that various micro-organisms produce di-carbonic acid, e.g., typical gastrointestinal bacteria and certain strains of lactobacilli. In addition, a new concept of biorefining has been introduced where cereals (e.g., sugar cane, maize) are used as raw material for microbial production of succinic acid [51].

Compared to the petrochemical process, the fermentation process has the advantages of mild conditions and independence from mineral feedstocks. However, the separation and purification processes and longer fermentation time are some of the main disadvantages of the fermentation process. The critical step in the fermentation process is mainly the purification of acetic acid from bicarbonate, which causes about $60-70 \%$ of the total byproduct. However, both industry and academia are trying to find more productive microbial strains and improve the competitive position of the fermentation process [52].

Succinic acid is also used as a precursor of many commodities or specialty chemicals, including adipic acid and 1,4-butanediol (BDO). To produce BDO, a three-step process is commonly used: firstly, maize glucose is fermented to form benzoic acid; then, it is purified by electrodialysis, and finally, benzoic acid is catalytically reduced to BDO. Significant investments have been made for the production of BDO of biological origin [53].

In Italy, Novamont inaugurated in September 2016 the first plant dedicated to the industrial-scale production of 1,4-butanediol directly from sugar using different bacteria [54]. Even though at the end of December 2016, Showa Denko (SDK) ended the production and sale of Bionolle ${ }^{\mathrm{TM}}$ due to the harsh market environment for biodegradable plastics and the delay in permeation of environmental regulations on plastic shopping bags, several companies are now scaling bio-succinate production processes that have traditionally suffered from poor productivity and high downstream processing costs [55]. Mitsubishi Chemical (Japan) has industrialized succinic acid derived from biomass in conjunction with Ajinomoto to put onto the market bio-based PBS. In parallel, DSM and Roquette are increasing the attention on a feasible fermentation process to produce succinic acid 1,4-butanediol and successive achievement of bio-based PBS. Myriant and Bioamber 
have developed fermentation technology to produce monomers for obtaining bio-based PBS [56].

Summing up, in 2020, there were companies around the world developing technologies for the production of PBS, as listed in Table 1 [57].

Table 1. Global producers of PBS (Reprinted with permission from Reference [57] Copyright 2020 Elsevier).

\begin{tabular}{cccc}
\hline Company & Location & Brand Name & Production (Kton/Year) \\
\hline BASF & Germany & PBS & not available \\
\hline Dupont & USA & PBST & not available \\
\hline Hexing Chemicals & China & PBS & 3 \\
\hline IPC-CAS & China & PBS, PBSA & 5 \\
\hline IRE Chemical & Korea & PBS, PBSA & 3.5 \\
\hline Kingfa & China & PBSA & 1 \\
\hline $\begin{array}{c}\text { Mitsubishi Gas } \\
\text { Chemical }\end{array}$ & Japan & PBS, PBSA, PES & 3 \\
\hline Showa & Japan & PBS, PBSA & 3 \\
\hline SK Chemicals & Korea & Skygreen & not available \\
\hline
\end{tabular}

\section{Thermal, Morphological, and Mechanical Properties}

As briefly mentioned in the introduction, PBS is a semi-crystalline polymer that presents a melting point at around $115{ }^{\circ} \mathrm{C}$ and HDT (heat distortion temperature) at about $97^{\circ} \mathrm{C}$ [58]; the tensile yield strength of non-oriented specimens is about $30-35 \mathrm{MPa}$, and it is a very ductile polymer (elongation at break more than 300\% [59]) with an elastic modulus in the range of 300-500 MPa depending on the crystallinity degree; it is well known that this influences the final stiffness of the material, the transparency, and the flexibility [60].

In terms of the elastic modulus evaluation, Righetti et al. [61] studied the elastic moduli of the crystalline and mobile amorphous fractions of PBS through a mechanical modelling approach, isolating the two contributions.

When crystallized, PBS forms spherulites; Figure 3 shows the typical radiating lamellar crystals of PBS spherulites [62], and it can also be observed how the crystallization temperature influences the morphology and the size of the spherulites. The time for the growth of a single PBS crystal depends on the temperature from 1 to $36 \mathrm{~h}$ as the crystallization temperature increases from $30^{\circ} \mathrm{C}$ to $62^{\circ} \mathrm{C}$.

The crystal structures of PBS have been extensively investigated in the literature using different experimental techniques: $X$-ray diffraction, electron microscopy, and $C$ NMR [63-66]. PBS has two crystalline forms: $\alpha$ and $\beta$. The PBS $\alpha$-form crystal system of is monoclinic form with unit cell dimensions as follows: $a=0.523 \mathrm{~nm}, b=0.908 \mathrm{~nm}$, $c=1.079 \mathrm{~nm}, \beta=124^{\circ}$ with a $\mathrm{T}_{7} \mathrm{GT} \overline{\mathrm{G}}$ chain conformation [63]. The structure of the $\beta$-form was investigated by Ichikawa et al.; they proposed that the $\beta$-form has unit cell dimensions as follows: $\mathrm{a}=0.584 \mathrm{~nm}, \mathrm{~b}=0.832 \mathrm{~nm}, \mathrm{c}=1.186 \mathrm{~nm}, \beta=132^{\circ}$ with $\mathrm{T}_{10}$ helical chains $[64,67]$. However, although PBS has these two crystalline structures, Ichikawa et al. [64,67] proved that the $\beta$-form modification exits only under strain, and this structure can return to the $\alpha$-form after removing the strain. Consequently, in most experimental conditions, only the $\alpha$-form exists.

Figure 4 shows the WAXD patterns acquired at room temperature of PBS films isothermally crystallized at different temperatures $\left(70,80,90\right.$, and $\left.100{ }^{\circ} \mathrm{C}\right)$. It can be observed that all WAXD patterns have identical diffraction peaks, showing that they have equal crystalline structures even if the crystallization temperature is not the same. In particular, the diffraction peaks correspond to the $\alpha$-form of PBS having three main characteristic peaks located at $2 \theta=19.7^{\circ}, 21.9^{\circ}$, and $22.8^{\circ}$ assigned to the (lllll), $\left.20 \begin{array}{lll}0 & 2 & 1\end{array}\right)$, and $\left(\begin{array}{lll}1 & 1 & 0\end{array}\right)$ planes [63]. 

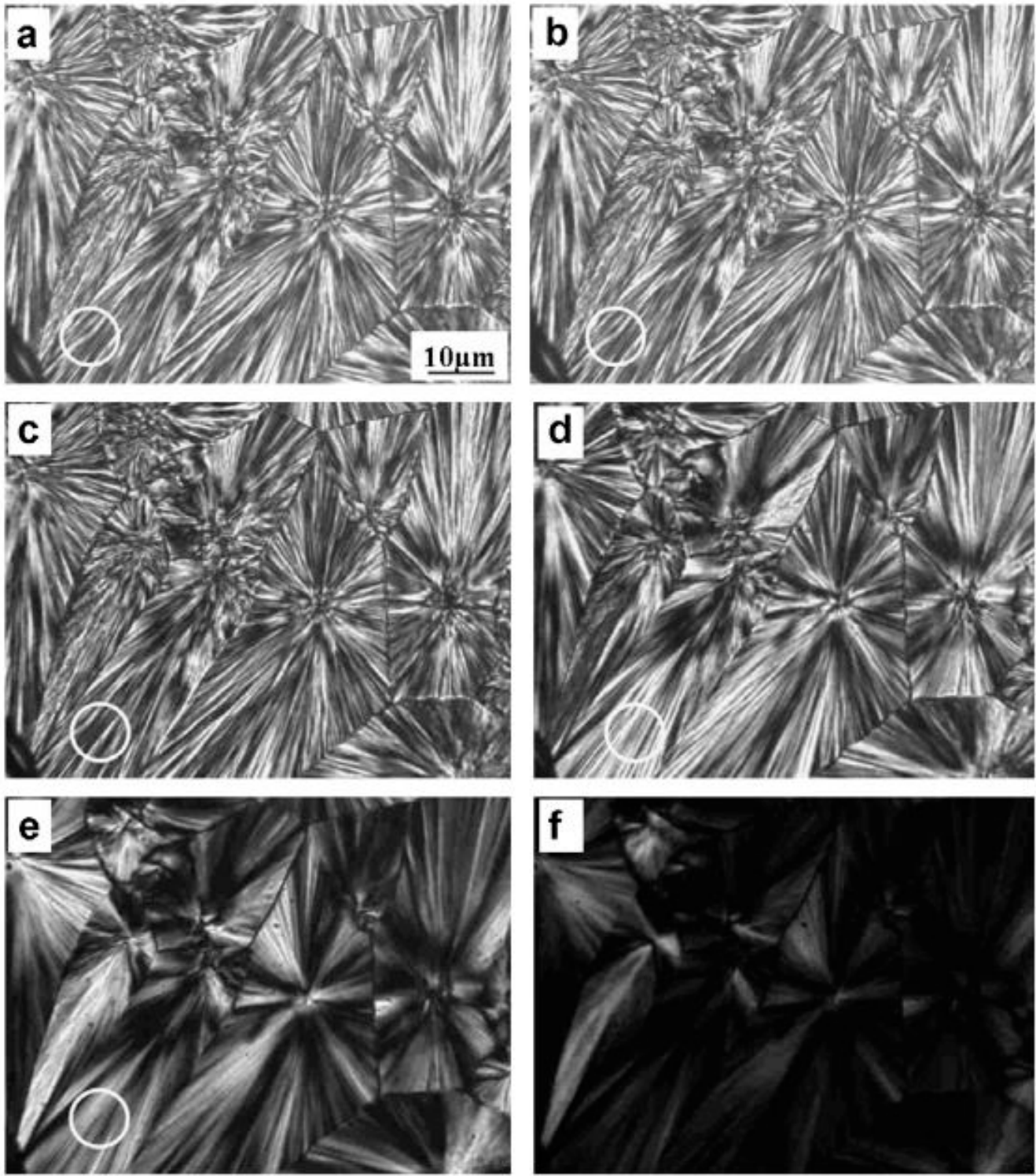

Figure 3. $\mathrm{OM}$ images of $\mathrm{PBS}$ spherulites crystallized at $90{ }^{\circ} \mathrm{C}$ during a heating scan at $10^{\circ} \mathrm{C} \mathrm{min}^{-1}$ : (a) $90{ }^{\circ} \mathrm{C}$; (b) $95^{\circ} \mathrm{C}$; (c) $104{ }^{\circ} \mathrm{C}$; (d) $107{ }^{\circ} \mathrm{C}$; (e) $112{ }^{\circ} \mathrm{C}$; (f) $115^{\circ} \mathrm{C}$ (Reprinted with permission from Reference [62] Copyright 2007 Elsevier).

Thermal analysis, performed by a differential scanning calorimetry (DSC) technique applied to PBS isothermally crystallized from the melt, revealed that PBS exhibits multiple melting behaviors. Four melting endotherms and a crystallization exotherm peak can be observed (Figure 5) [62]; at each transition, different mechanism were attributed. In particular, the crystallization exothermic peak has been explained in connection with the melt recrystallization of the crystallites that have poor thermal stability. The endothermal peaks are attributed to the following: (1) re-melting of crystallites shaped during re-crystallization; (2) different type of crystals; and (3) annealing peak at which the transition of the rigid amorphous fraction (RAF) from solid-like RAF into a liquid-like amorphous fraction occurs [68]. 


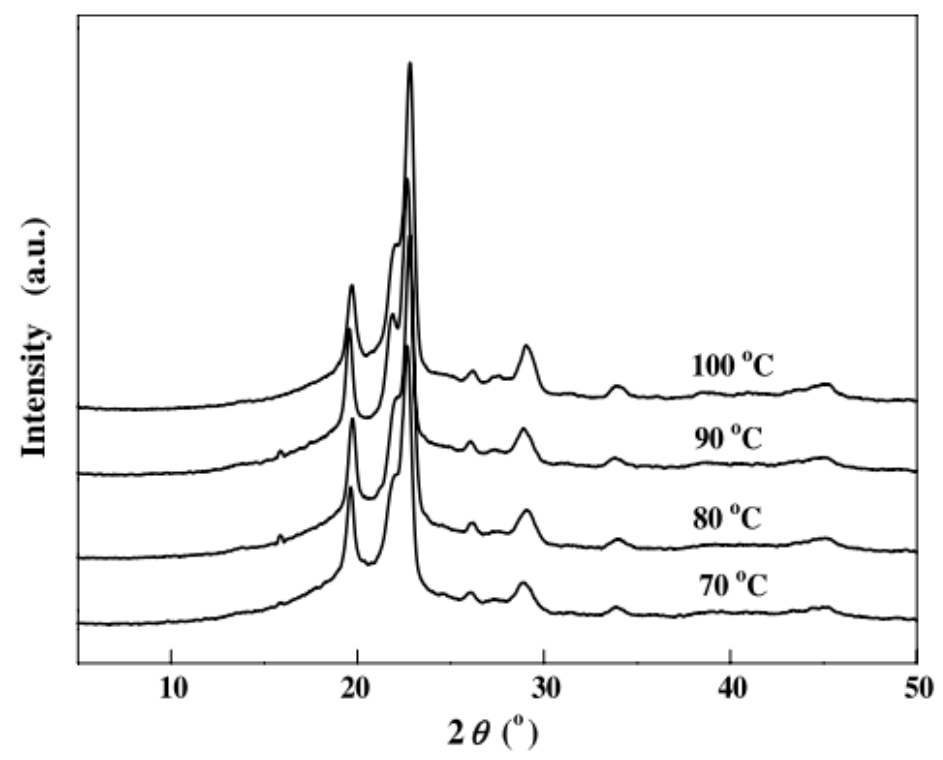

Figure 4. Wide-angle X-ray diffraction patterns of PBS after being crystallized isothermally from the melt at different temperatures. (Reprinted with permission from Reference [62] Copyright 2007 Elsevier).

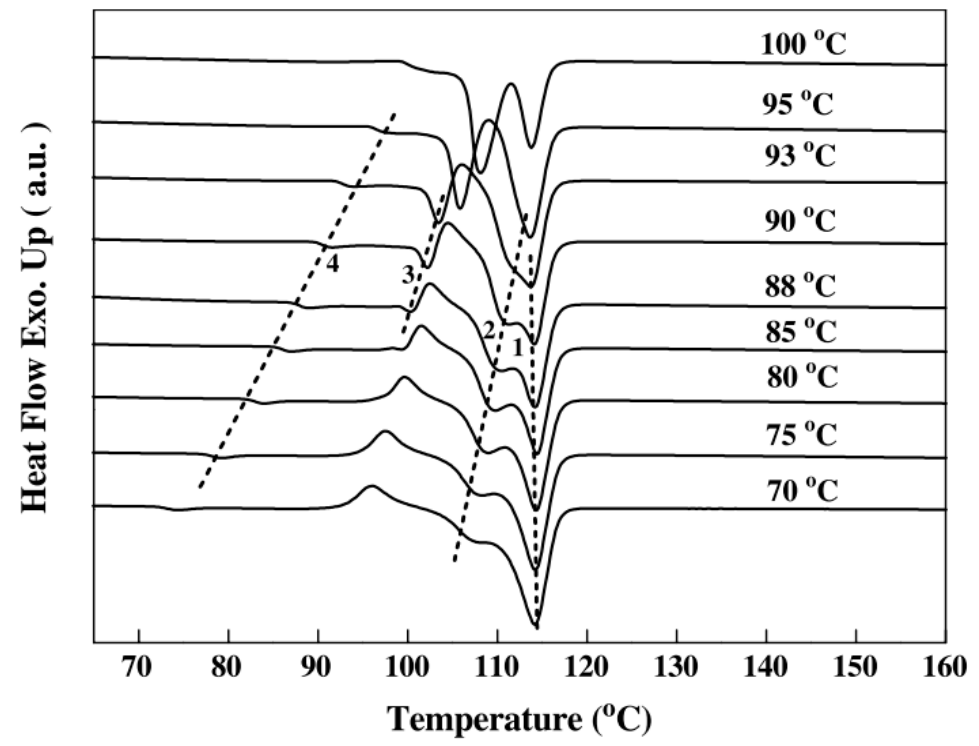

Figure 5. Standard DSC melting curves of PBS samples crystallized at different temperatures as indicated. The heating rate is $10^{\circ} \mathrm{C} \mathrm{min}$. The dashed lines are the indications of four melting peaks. (Reprinted with permission from Reference [62] Copyright 2007 Elsevier).

Regarding this last point, Wang et al. [62] observed that the annealing peak is present in all melting curves and its position is higher than the corresponding Tc. The same behavior can be found in literature for other polymeric systems [69-73].

However, to complete the investigation of the PBS properties, the behavior of PBS itself must be known as well as its copolymers properties. In fact, the physical properties of PBS copolymers vary with the co-monomer content. The use of copolymers allows us to tailor the physical properties of PBS according to the final application. Among the different copolymers that have been investigated in literature, the following should be mentioned: adipic acid [74,75], terephthalic acid [76,77], methyl succinic acid [78,79], benzyl succinic acid [80], and ethylene glycol [81-83].

Depending on the copolymer miscibility, different crystallization behaviors can be found. The comonomer units can be excluded from the crystallization phenomenon and 
thus they remain in the amorphous phase; otherwise, they can co-crystallize. In the latter case, it is possible to distinguish between two cases of co-crystallization: isomorphic (in which only one crystalline phase is present that contains both comonomer units with no dependence on the composition range) and isodimorphic (in which there are two crystal structures that depend on the composition) $[84,85]$.

Regarding mechanical properties, the copolymerization generally leads to an increase in the elongation at breakage and the impact strength but a decrease in the tensile strength, increasing the amount of the secondary component [86]. The thermal properties decrease with a decrease in the heat distortion temperature, crystallinity degree, and melting point. An exception to this rule is presented by poly(butylene succinate-co-butylene fumarate) that exhibits a constant melting point with the copolymer composition up to $20 \%$ mol [74].

Generally, for the common PBS copolymers, in order to maintain the melting point of PBS-copolymer systems around $100{ }^{\circ} \mathrm{C}$, the content of the comonomer units is kept lower than $15 \%$ mol.

Noteworthy is the behavior of the PBSA copolymers that exhibit an intermediate behavior between PBSA and poly (butylene adipate) PBA depending on their composition. As can be observed in Figure 6, as the adipate unit increases, the glass transition $\left(T_{g}\right)$ and melting temperature $\left(\mathrm{T}_{\mathrm{m}}\right)$ decrease and pass through a minimum at a copolymer composition close to equi-molarity (adipate unit $(\mathrm{mol} \%)=62 \%)$. Then, when $62 \%$ of the adipate unit is passed, the temperature values increase toward the value of PBA $[6,44,86]$.
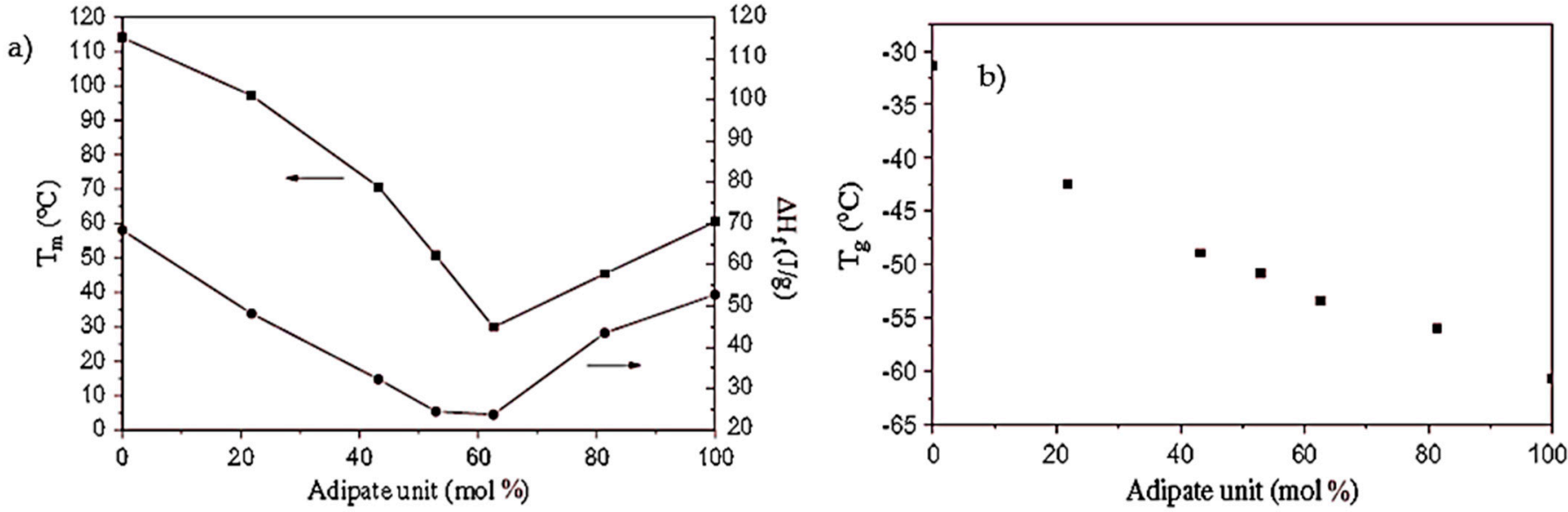

Figure 6. (a) Copolyester melting temperature and heat of fusion as a function of the composition. (b) Copolyester glass transition temperature as a function of the composition. (Reprinted with permission from Reference [6] Copyright 2001 Wiley).

The glass transition temperature trend showed that the succinate and adipate units act as soft segments leading to a glass transition temperature [6]. The melting behavior, on the other hand, can be explained considering the interaction between the two different succinate and adipate segments. They act as impurities in the copolymer macromolecular chains, leading to the formation of less perfect crystals and reducing the crystal size of the homopolymers. Figure 7 shows the morphologies of melt isotactic PBS and PBA homopolymers and PBSA copolymers, and it can be noticed how the PBS spherulite dimensions are considerably higher, which means that with an increasing amount of adipate units, the spherulite dimensions become smaller [45]. 


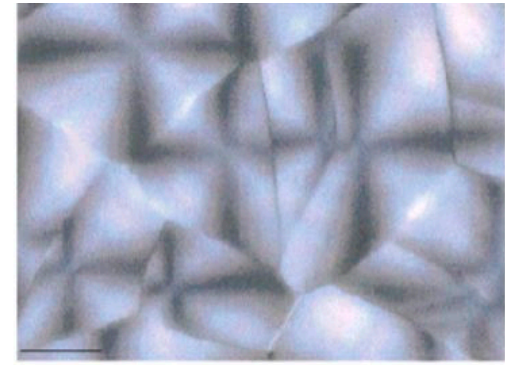

(a)

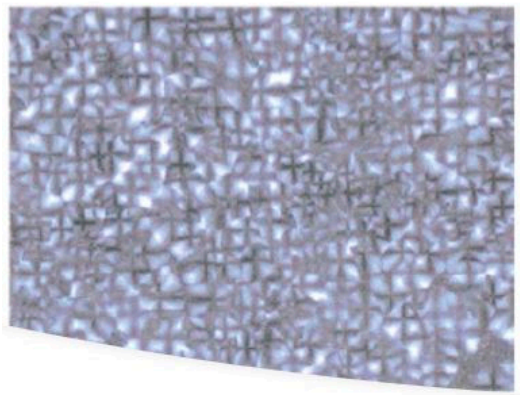

(d)

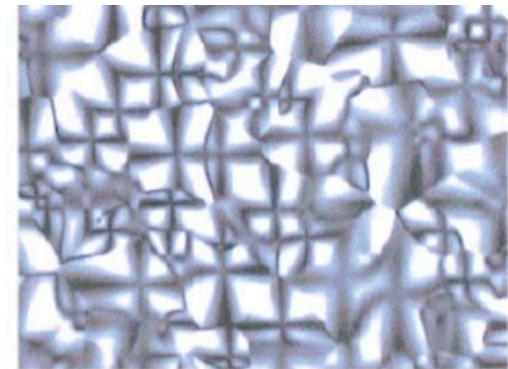

(b)

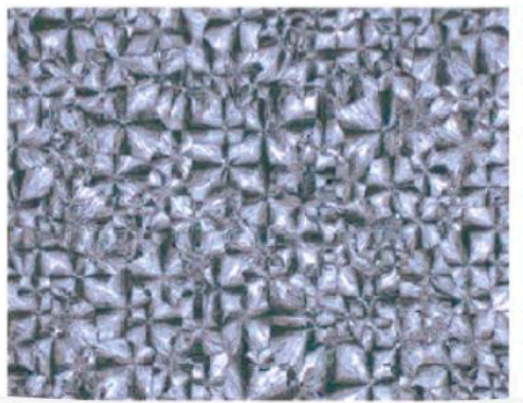

(e)

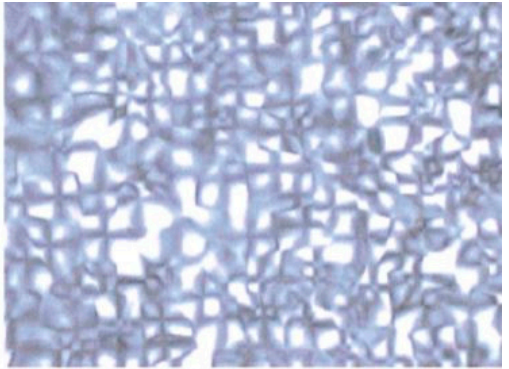

(c)

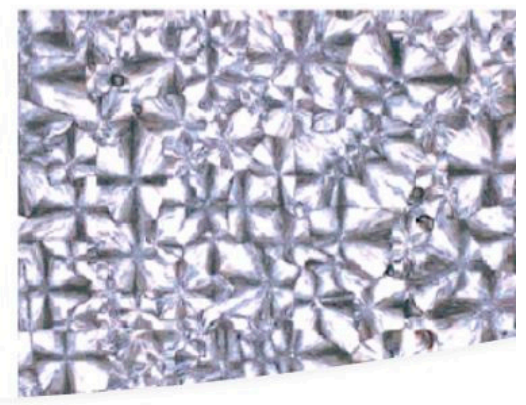

(f)

Figure 7. Polarizing optical micrographs of succinate-based copolymers: (a) PBS; (b) PBSA, adipate unit $(\mathrm{mol} \%)=21 \%$; (c) PBSA, adipate unit $(\mathrm{mol} \%)=41 \%$; (d) PBSA, adipate unit $(\mathrm{mol} \%)=49 \%$; (e) PBSA, adipate unit $(\mathrm{mol} \%)=80 \%$; (f) PBA. (Reprinted with permission from Reference [6] Copyright 2001 Wiley).

It has been shown that the crystallinity degree has the same trend as the melting temperature, and by increasing the adipate content, the crystallinity degree decreases, reaching a minimum value of about $50-60 \%$ (Figure 8 ), and then starts to increase again toward the PBA crystallinity value. This tendency is in accordance with the possibility of the reduction of the homopolymer crystallite size caused by the appearance of the second base unit [87].

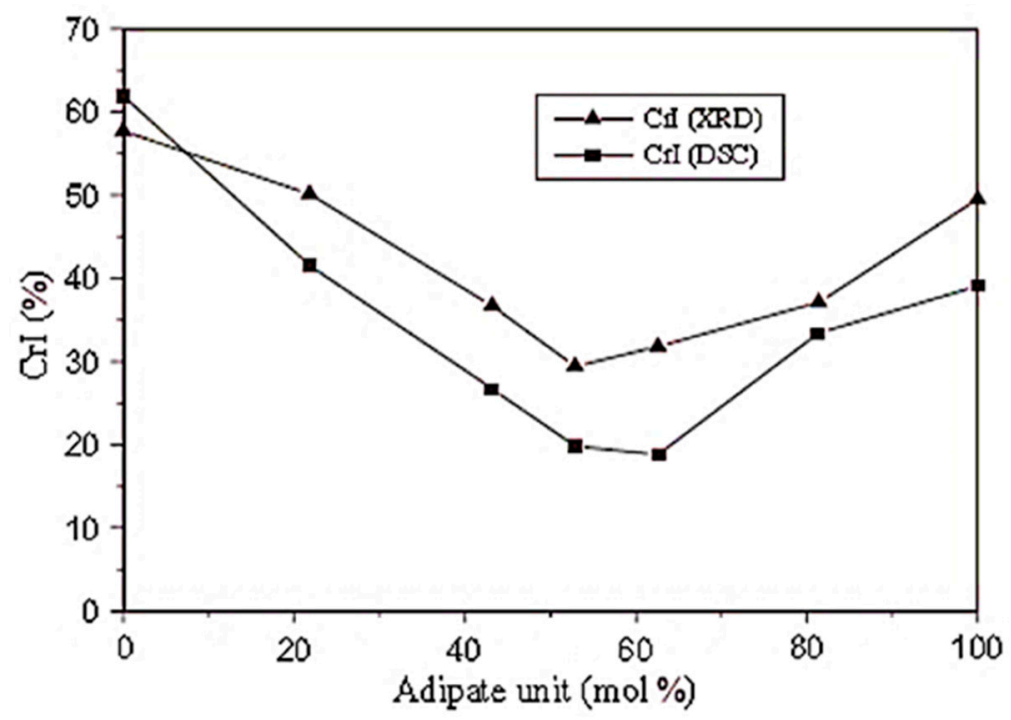

Figure 8. Copolyester crystallinity index as a function of the adipate unit composition (Reprinted with permission from Reference [45] Copyright 2006 Elsevier).

Because the crystallinity is associated with the mechanical properties, it follows that the most crystalline polyester, PBS, retains the maximum tensile strength; by increasing the 
adipate units, the tensile strength decreases, reaching the value of PBA. However, the loss of tensile strength and the molecular weight must be considered. In fact, it is an important parameter able to affect the final properties of the material [88].

However, this decrement in the tensile strength with the decrease in the molecular weight and/or the increase in adipate units increases the elongation at breakage.

\section{Blends with PBS}

Blending two different polymers is a promising method to improve the material performance. Regarding bio-based and biodegradable materials, PBS has been blended with other polymers, mainly polylactic acid, starch, polyhydroxybutyrate, and proteins [43]. Principally, PBS is used as a ductility enhancer for PLA; its main defect is the brittleness. A PBS copolymer with an adipate segment, PBSA, is also present in many works regarding the improvement of toughness for brittle matrices concerning the creep behavior [89].

PLA/PBS immiscible blends favor the enhancement of the tensile properties such as elongation at breakage [90], improving the cold-crystallization of PLA [91]. Liu et al. [92] reported that when the blending range is from $80 / 20$ and 20/80, the dispersed phase is finely distributed in the matrix, with the size around several microns, as demonstrated. As a result, PBS/PLA and PBSA/PLA blends demonstrate good mechanical properties, and only a small amount of PBS or PBSA (20 wt.\%) can turn PLA from brittle to ductile, increasing the elongation break from $25 \%$ to more than $200 \%$. They are compatible during melt processing although they are not miscible at a molecular level [93].

Recently, Gigante et al. [94] investigated PLA/PBS-based blends both on a laboratory and a semi-industrial scale, showing the subsequent plasticization migration $[95,96]$. By considering the effect of different additives, selected blends were processed by using flat die extrusion to obtain biocompatible films. The films produced by flat die extrusion showed improved flexibility, elongation at breakage, and better tear resistance with respect to pure PLA, and was competitive in performance against fossil-based polyolefins. Moreover, the PLA film and the blends showed higher biocompatibility, which was tested by using keratinocytes and mesenchymal stromal cells, with respect to LDPE and a slight antimicrobial effect.

Ojijo et al. [97] studied PLA/PBSA blends in the entire composition range. Fourier transform infrared measurements revealed that there was no chemical interaction among them, resulting in morphological phase separation. It was interesting to evaluate the interface, which, in terms of PBSA droplets, reached a maximum point for the blend with $70 \mathrm{wt} . \%$ of PLA. The authors pointed out that thermal stability and mechanical properties were dependent mainly due to the interface between the two polymers compared with the blend composition.

Furthermore, Messin et al. [98] demonstrated that PLA/PBSA multilayer films produced by co-extrusion technology did not show delamination. The structural changes due to an increase in the rigid amorphous fraction (RAF) in PBSA significantly improved the vapor and gas barrier properties of the multilayer film more than double compared with pure PLA.

Key thermal characterization parameters for binary blends of PLA and PBSA were evaluated by Yokohara et al. [32]; they stated that mixing PBS with PLA improved the crystallization of PLA. This is a very interesting phenomenon, since the melted PBS droplets serve as crystallization cores for PLA. Furthermore, the PLA crystallites produced during the quenching process were responsible for the improved behavior of the blends in cold crystallization.

With regards to blends between PBS and PHBV, the literature is not as rich as that for PLA/PBS blends. In one of these articles, Ma et al. [99] found that the compatibility between PHBV (or PHB) and PBS was poor, resulting in a relatively large particle size and weak interfacial adhesion in their blends. To improve the compatibility, in situ compatibility of PHBV/PBS blends was performed in the presence of DCP (dicumyl peroxide). This improved the mechanical properties of the mixtures from $<10$ to $400 \%$ for the PHBV / PBS 
blend (80:20) and Izod impact values without indentation from 10 to $50 \mathrm{~kJ} / \mathrm{m}^{2}$ for the PHB/PBS mixture (70:30). The results showed that matrix shrinkage combined with expansion, deformation, and fibrillation of PBS particles and partial cross-linking of the blends contributed to the increased toughness of the compatible blends.

In recent work [29], biopolymer blends of PBS and plasticized whey protein (PWP) derived from a natural by-product of the cheese industry were inspected for film/sheet extrusion and subsequent production. Several formulations were studied, increasing the content of protein until $50 \mathrm{wt} . \%$. Soya lecithin and a modified Schotten-Baumann method were also used to improve the compatibility of the blends. Young's modulus increases, correlated with improvements of the tensile strength and elongation at breakage, were observed. Through DSC analysis, it was also found that these compatibilizers increased the crystallinity of PBS.

Another solution found in the literature to improve the mechanical properties of pure constituents was the production of a blend with PBS and thermoplastic starch (TPS) [100]. This can be a useful method to decrease the water absorption of starch-based plastics. The mechanical properties of TPS were significantly improved after mixing with PBS, and the tensile strength increased up to ten times, even though only $10 \mathrm{wt} . \%$ PBS was added. The water absorption of the mixture decreased significantly with respect to pure TPS, and this product could also find wider applications due to the complete bio-based nature.

Finally, Seggiani et al. [101] investigated mixtures of poly(butylene succinate-coadipate) (PBSA) and crude hydrolyzed collagen (HC), a by-product of the tanning industry, by extrusion/molding and with regard to the thermal, rheological, and mechanical properties. Blown films made with up to $10 \% \mathrm{HC}$ by weight were found to be flexible, with satisfactory tensile properties and excellent tear resistance. On the other hand, blends with a higher HC content (up to $20 \%$ by weight) were suitable for injection molding, resulting in good tensile properties ( $5 \%$ by weight of HC; the maximum elongation at breakage was $1200 \%$ ).

\section{Composites with PBS}

Biocomposites, also known as natural fiber composites, are defined as composite materials in which the reinforcement is a biodegradable natural fiber bonded to a biodegradable or non-biodegradable polymer matrix. The development of biocomposites allows a balance between economic and environmental concerns, as well as customization of the final material properties [102].

Among the aliphatic polyesters, PBS is a promising alternative for the production of high-performance and environmentally friendly biodegradable plastic composites [103]. The excellent processability of PBS in the fields of textiles and injection-molded products makes it a very versatile polymer [104]. However, the PBS has some drawbacks, such as excessive softness, a poor gas barrier property, and excessive low viscosity not sufficient for some end-use applications, which must be overcome. For this purpose, the use of PBS matrix composites is therefore necessary to overcome the limits of the starting matrix.

Conducting polymers have attracted considerable attention due to their potential applications in many sectors such as energy storage, sensors, electromagnetic shielding, corrosion, microelectronics, electrochromics, etc. $[105,106]$. In particular, great potential can be expected from biocomposites that couple renewability and biodegradability for high dielectric constants and dielectric loss factors to be used as substrates or semiconductors for electronic applications [107].

In this context, the development of PBS nano composites has revealed a feasible approach to obtain enhanced conductive properties with an acceptable cost [108].

Although high-temperature applications (i.e., beyond $150^{\circ} \mathrm{C}$ ) are of great interest for many electronics applications, achieving stable carrier mobilities for organic semiconductors at elevated temperatures is fundamentally challenging [109]. Since the discovery of carbon nanotubes (CNTs) in 1991, [110] received much attention for the impressive properties of CNTs such as the high modulus and high electrical/thermal conductivity; the incorporation of CNTs into PBS was investigated in the literature also by Yarici et al. [111]. 
They found that the introduction of CNTs led to a moderate improvement of the tensile modulus and thermal stability, but the electrical conductivity of net PBS dramatically increased after the nanocomposite formation.

Sinha Ray et al. [112] reported that poly(butylene succinate) (PBS)/multi-walled carbon nanotube (MWCNT) nanocomposites not only ensure an increase in the tensile modulus and thermal stability of PBS, but the MWCNT addition dramatically improved the electrical conductivity (the plane conductivity changed from $5.8 \times 10^{-9} \mathrm{~S} / \mathrm{cm}$ for neat PBS to $4.4 \times 10^{-3}$ for the PBS based nanocomposite.

The addition of both CNT and organo-montmorillonite into a poly(butylene succinate)/polylactide (PBS/PLA) blend, as reported by Sivanjineyulu et al. [108], revealed a preferential distribution of the nano fillers among the two polymers: CNT that was distributed mainly in the PBS matrix, whereas organo-montmorillonite was selectively localized within the dispersed PLA domains, resulting in a decrease of the electrical resistivity of the blend by up to 11 orders at 3 phr CNT loading.

Promising academic results that can lead to a reduction of the environmental footprint for wearable electronics were achieved by Hsieh et al., who investigated a "green" environmentally friendly switching memory device constituted by a polyfluorene/poly(butylene succinate) (PFN/PBS) blend. In particular, the resistive switching memory device constituted by the AgNW/(PFN/PBS solution-sheared film)/AgNW/Ecoflex sandwich structure exhibited a high on/off current ratio of $10^{10}$, a low threshold voltage of $2.6 \mathrm{~V}$, and outstanding stability for $7000 \mathrm{~s} \mathrm{[113].}$

Great interest was also paid to polymer/layered silicate nanocomposites thanks to their capacity to exhibit remarkable improvement (high tensile modulus, high tensile strength, increased heat resistance, and increased biodegradability of biodegradable polymers [114,115]). For this purpose, PBS/organically modified layered silicate nanocomposites were investigated correlating the morphology to the rheological properties [116] and also evaluating the final effect on the final thermal $[90,117]$ and mechanical properties [118-121].

To improve the strength and stiffness of PBS and at the same time to reduce the weight of the resulting product, the addition of natural fibers can be a valid alternative; nevertheless, it must be always kept in mind that the properties of natural fibers vary with their sources and treatment. Therefore, great attention must be paid in selecting the type of natural fiber to be adopted [122,123].

Despite the positive characteristics of PBS, its high cost, compared to other conventional plastics, limits its use. For this purpose, different composites materials have been developed with the aim to obtain a new composite material and at the same time to reduce the overall cost of the manufactured material by inserting fiber waste.

In the literature, different attempts have been made in this sector, adding to PBS several types of natural fibers $[124,125]$ and natural wastes such as rice straw [126], jute fibers [92], pineapple fibers [127], bamboo fibers [128] or hemp fibers [129]. However, compatibility with the matrix is fundamental to achieve a significant enhancement of PBS composites; for example, in the work of Liminana et al., interesting results were achieved for PBS composites containing $30 \mathrm{wt} . \%$ of almond shellflour (ASF) by using appropriate compatibilizers [128]. Effective compatibilization was obtained with silane treatment. In PBS/cotton fiber composite systems, the silane treatment improved the tensile strength up to $25-118 \%$ with the incorporation of $10-40 \mathrm{wt} . \%$ of cotton fibers [130]. In the preparation of an innovative PBS/spirulina composite, it was necessary to synthesize a maleic anhydridegrafted PBS (PBS-g-MAH) to ensure compatibility of the composites and to obtain adequate final mechanical properties [131].

Not only fibers from vegetable sources but also animal-based fibers must be compatibilized. The use of animal-based natural silk fibers as reinforcement was investigated by Lee et al. [132]. They demonstrated that chopped silk fibers play an important role in improving the starting mechanical properties of PBS, but a surface modification is needed to enhance the interfacial adhesion and thus the stresses transferred from the matrix to the fibers [133]. 
Frollini et al. [134] studied the potential of different lignocellulosic fibers, especially curaua fibers. They suggested that the biocomposites obtained could have various applications, for example, in rigid packaging and interior parts of cars.

\section{Biodegradability}

Environmentally degradable plastics can degrade into $\mathrm{CO}_{2}$ and water through naturally occurring degrading enzymes and microorganisms after disposal [135]. PBS and its copolymers are not to be outdone. The growing concern for environmental issues is leading these plastics to find wider applications [136].

The biodegradability of polyesters is affected by different factors: molecular weight, degree of crystallinity, and chemical structure. In particular, considering the chemical structure, the hydrolysable ester bond in the main chain, which is susceptible to microbial attack, is the major reason for polymer biodegradation [137].

The degradation of PBS can be studied with different methods: hydrolytic degradation and enzymatic and biodegradation under environmental conditions, such as activated sludge, soil burial (according to the ISO 846) and compost. In all methods, the degree of biodegradation is estimated by the sample weight loss, by considering the loss in the mechanical properties and by examining the surface morphology using scanning electron microscopy (SEM) [138].

The behavior of PBS has attracted the attention of different studies. Kanemura et al. [139], for example, studied the consequences of the contact with $\mathrm{H}_{2} \mathrm{O}$ in the biodegradability of polyesters. Films of PBS sized $70 \mathrm{~mm} \times 10 \mathrm{~mm} \times 3 \mathrm{~mm}$ were submerged in distilled water at several temperatures, and 3-point bending tests were carried out (oscillating from $0 \mathrm{~h}$ to $1500 \mathrm{~h}$ ). It has been pointed out, as shown in Figure 9, that the bending strength of PBS immersed in $25^{\circ} \mathrm{C}$ water remained almost constant after $1500 \mathrm{~h}$ of immersion time (Figure 9).

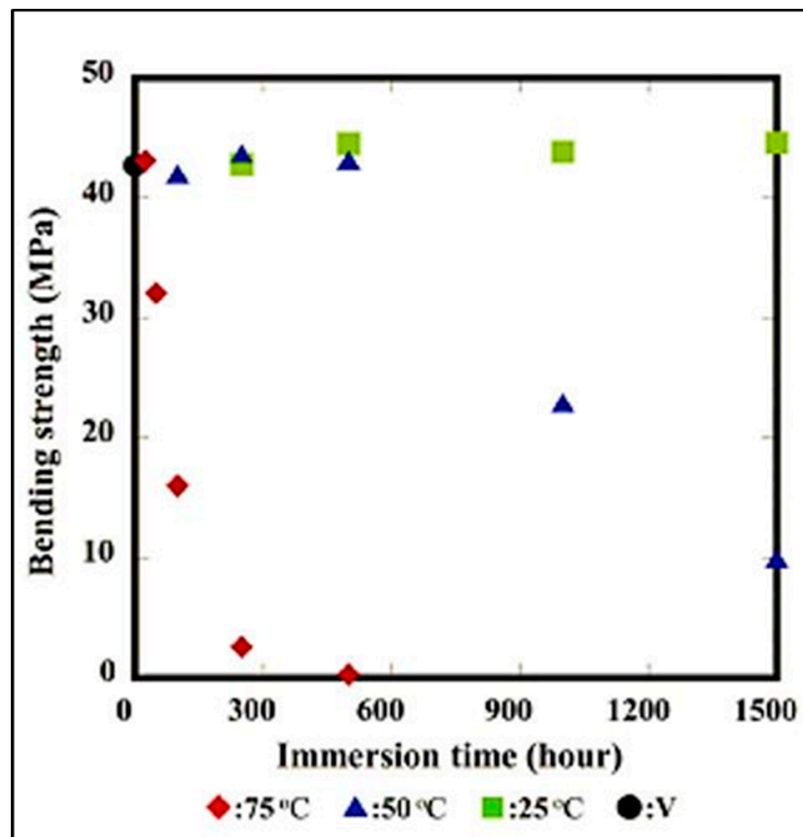

(a)

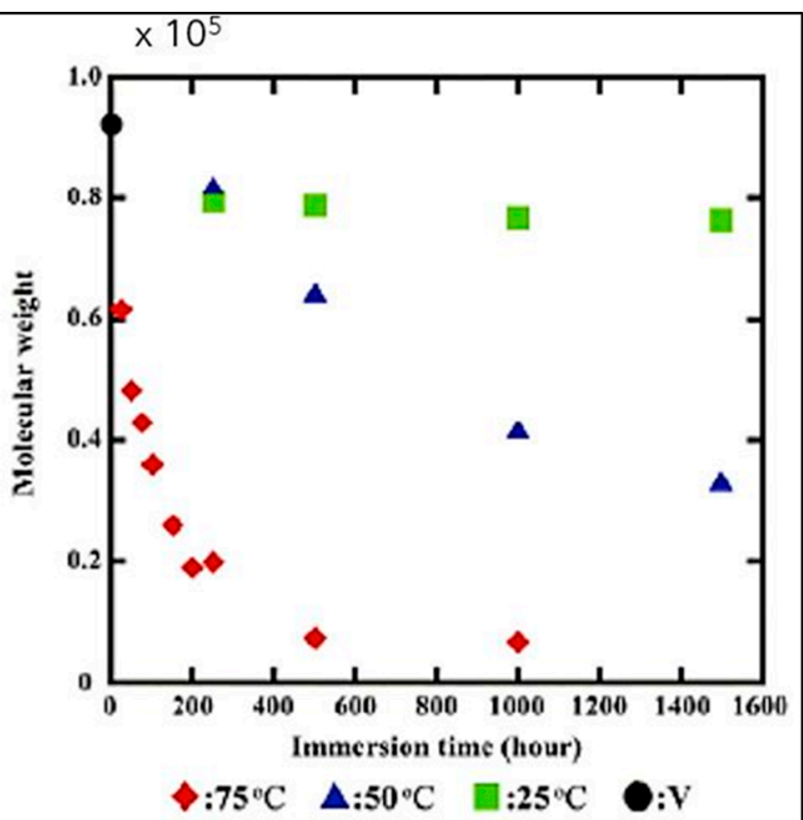

(b)

Figure 9. (a) Bending strength and (b) Molecular weight of PBS vs. immersion time at different temperatures (Reprinted with permission from Reference [139] Copyright 2012 Elsevier).

The decrease in the molecular weight is mainly due to the chemical degradation caused by hydrolysis and appears meaningful when PBS is immersed in $50^{\circ} \mathrm{C}$ and $75^{\circ} \mathrm{C}$ water. 
To completely evaluate the performance of PBS in water, Kanemura et al. [139] also examined the properties of reprocessed PBS. They compared the flexure stress and molecular weight of non-reprocessed and reprocessed PBS dipped in water at a temperature of $75{ }^{\circ} \mathrm{C}$. The recycling procedure consisted of crushing into powder the material with a freezing plastic mill, drying the pieces, and then molding sheets of PBS under accurate thermodynamic conditions.

Figure 10 shows the results of comparing processed and unprocessed PBS, where the increase in the molecular weight indicates the possibility of PBS re-synthesis during the reprocessing process.

(a)

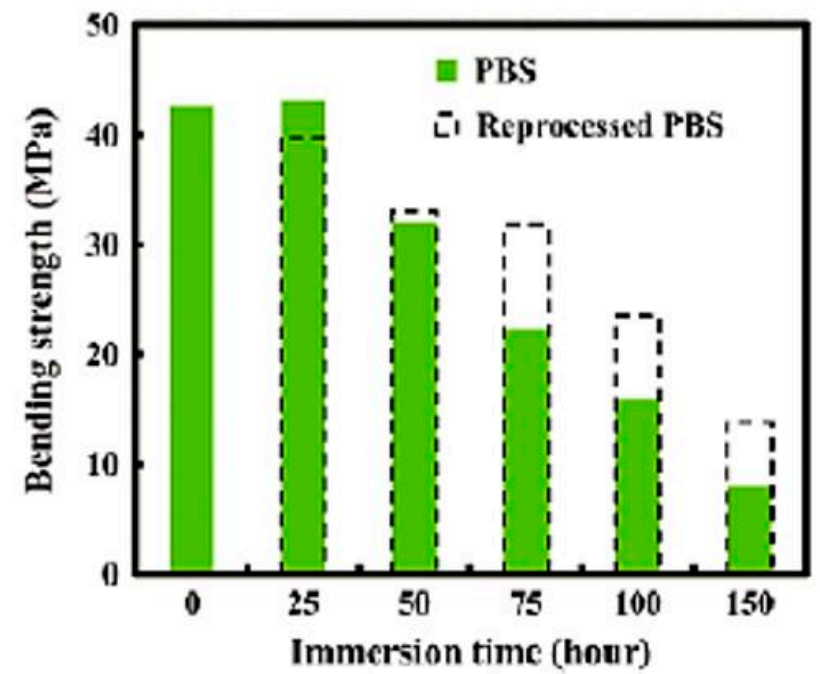

(b)

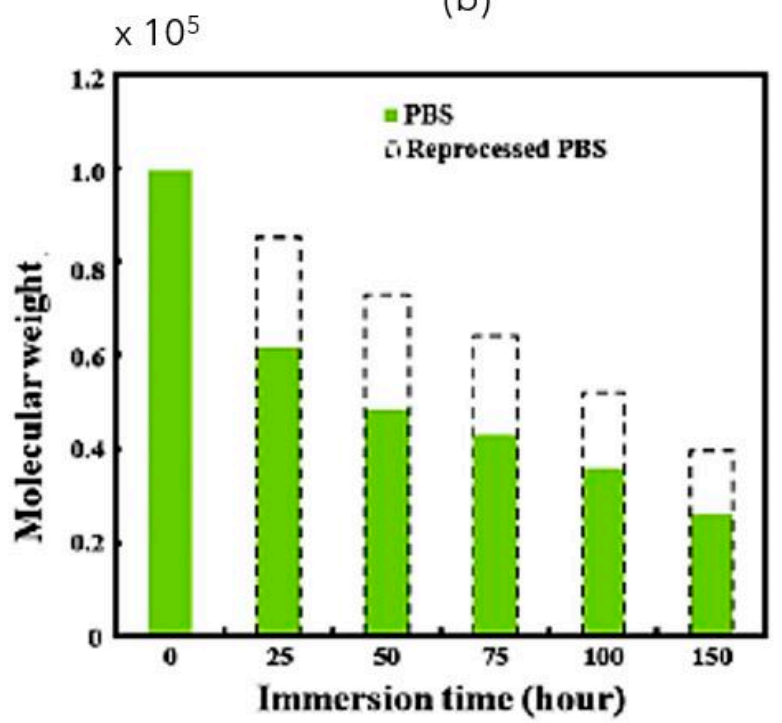

Figure 10. (a) Bending strength and (b) Molecular weight of PBS and reprocessed PBS (Reprinted with permission from Reference [138] Copyright 2012 Elsevier).

In other words, after the biodegradation and the reaction of ester bonds, in the reprocessing, the reaction between the low-molecular-weight polymer can advance in the opposite direction (not degradation but re-synthesis).

Furthermore, Ahn et al. [6] proposed that the presence of butenoic acid units may promote hydrophobicity in the copolymers, which would negatively affect the sensitivity to the hydrolytic reaction by sterically blocking the entry of nucleophiles.

The enzymatic degradation of aliphatic polyesters is related to their crystallinity and chemical structure. For aliphatic copolymers, such as PBSA, those with the lowest crystallinity exhibit the highest degradation rates [140]. Environmental biodegradation is sensitive to both polyester properties and the environment, such as moisture, microorganisms, and temperature. For example, Phua et al. [141] reported that various microorganisms capable of degrading PBS and its copolymers, including bacteria and fungi, have been isolated.

However, several studies $[45,142]$ estimated that when degraded in soil, PBS will lose weight at a speed of about $0.2 \%$ or $0.5 \%$ after biodegradation for 30 days.

For instance, Tserki et al. [44] reported the biodegradation in soil burial of PBS and PBSA copolymers as evidenced by Figure 11. 


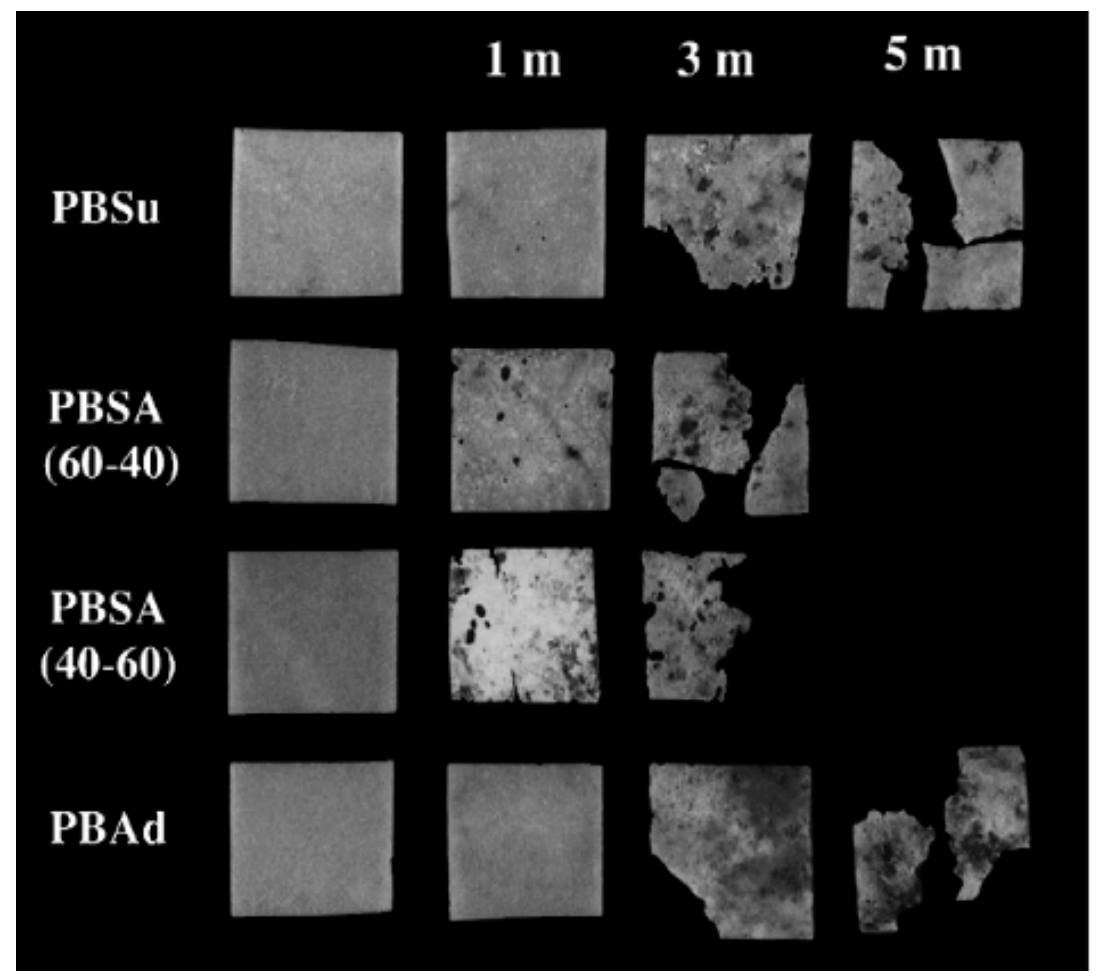

Figure 11. PBS and PBSA-based blends after soil burial treatment for 1, 3, and 5 months (Reprinted with permission from Reference [45] Copyright 2006 Elsevier).

Another important method of biodegradation is biodegradation in compost. The biodegradation rate of PBS in compost is sensitive to the size and shape of the specimen. PBS powder had a degradation rate comparable to that of the film, while pellets of PBS degraded more slowly [48].

These data were confirmed by Zhao et al. [143]; in their paper, the PBS biodegradation was evaluated under specific composting settings. The biodegradation level showed that the powder-formed sample had a higher value of biodegradation, and it can be explained considering the largest specific surface.

It is possible to underline, following the already cited work of Zhao, that the biodegradation in the first phase was slow and then accelerated, showing a final plateau. Four strains were isolated from the compost, and Aspergillus versicolor was the best PBSdegrading microorganism.

\section{Applications}

Definitely, PBS, its copolymer with adipic segment, and the blends with PLA, PHBV or TPS have found commercial applications in many fields [144] such as packaging, agriculture, fishery, forestry, construction, and electronics as demonstrated by Figure 12 [145].

For example, PBS and PBS/PLA blends have been employed as mulch films [146,147], packaging [148], and dishware (as stated by Pivsa-Art at al. [149]). In addition, they are used in foaming [150], drug encapsulation systems [151], orthopedic applications [152], coffee capsules [153], and the industrial field [154].

The processability of PBS is related to its molecular weight: a Mw of less than 100,000 is desirable for extrusion and injection molding; with higher Mw or long, branched chains, film blowing and casting can be used [155]. Thermal stability and a high crystallization rate are fundamental to ensure a smooth processing. To increase crystallinity and transparency, nucleating agents can be used [156].

The performance expected from bioplastic materials used in food packaging applications is to protect it from the environment and maintain food quality. In view of possible applications of PBS and PBSA, Siracusa et al. [157] considered films of PBS and PBSA and 
evaluated the permeability behavior and the changes after contact with foods. From the analysis, no severe damage of the materials was observed, and the results confirmed the potential of these materials for the food industry. Recent work showed the insertion in the market of PBS reinforced with natural plant fibers [158].
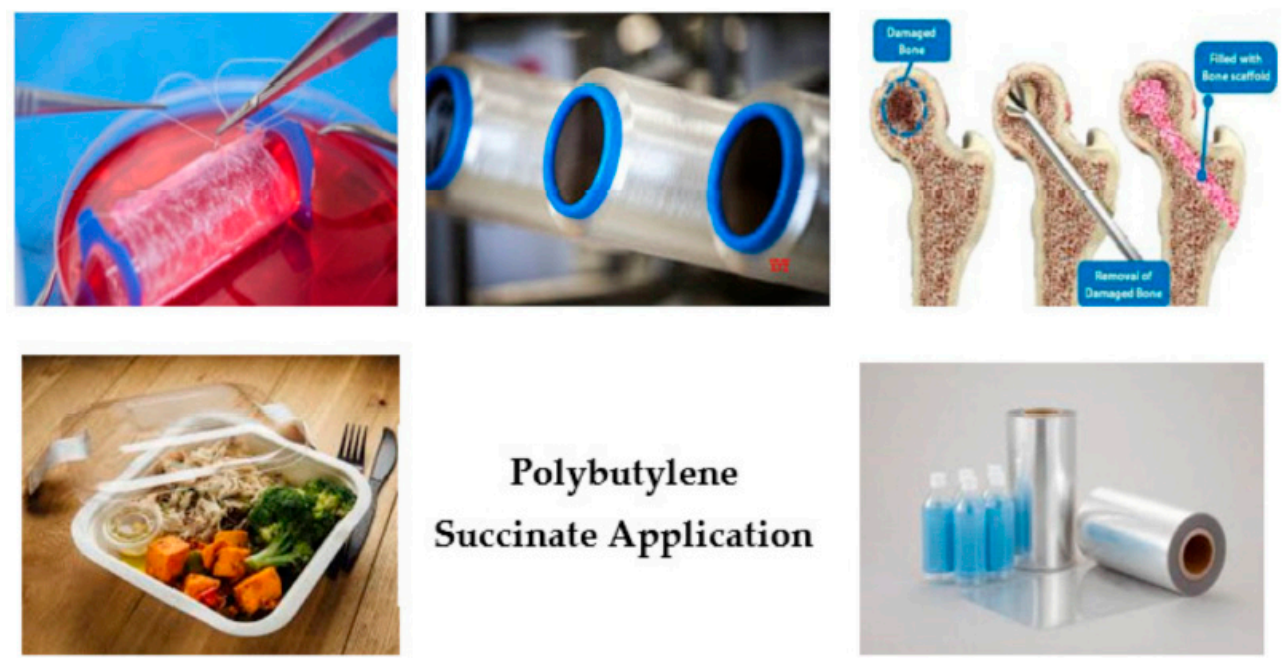

\section{Polybutylene}

Succinate Application
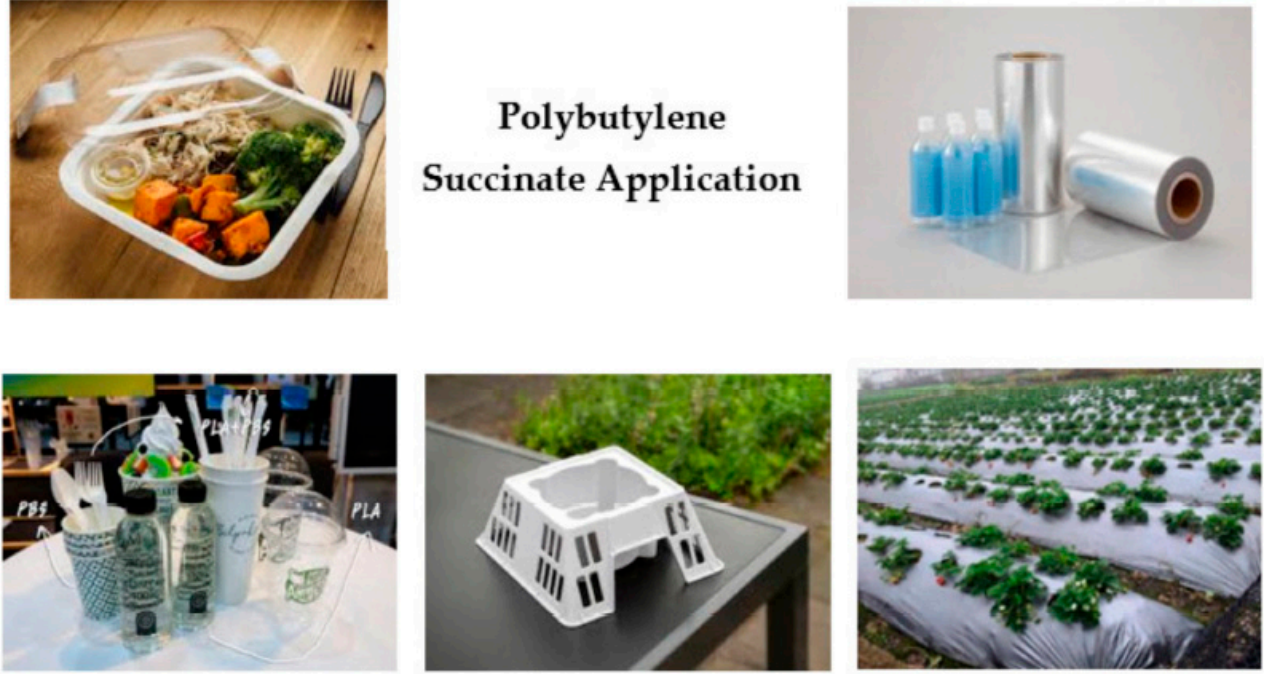

Figure 12. PBS applications [145].

\section{Conclusions}

This brief technical review aimed to substantially examine the current main knowledge and prospects of poly (butylene succinate) (PBS) and its copolymers, in particular poly (butylene succinate-co-butylene adipate) (PBSA). Owing to its balanced properties, good thermal processability window, and biodegradability, PBS and its copolymers are attracting much interest in this era of increasing environmental awareness. Furthermore, the properties and biodegradation rate of PBS can be tailored via copolymerization with different types and contents of comonomer units to meet various requirements.

At the present stage, several companies are planning to expand their manufacturing capabilities of PBS to meet the rapid increase in demand for biodegradable plastics, especially for packaging purposes. However, only future developments and a progressive change of mindset will make PBS and other bio-based polymers more and more present in our lives.

Author Contributions: Conceptualization, P.C. and M.S.; methodology, L.A. and V.G.; validation, P.C., M.S. and A.L.; investigation, V.G. and L.A.; resources, P.C., data curation, V.G. and L.A.; writing-original draft preparation, L.A. and V.G.; writing—review and editing, P.C., M.S. and A.L.; supervision, P.C. All authors have read and agreed to the published version of the manuscript.

Funding: This research received no external funding.

Institutional Review Board Statement: Not applicable.

Informed Consent Statement: Not applicable.

Data Availability Statement: Not available. 
Acknowledgments: For the knowledge acquired during the project, connected to the applications of PBS, we thank the ECOFUNCO project, funded by Biobased Industries Joint Undertaking under the European Union Horizon 2020 research program (BBI-H2020): 837863.

Conflicts of Interest: The authors declare no conflict of interest.

\section{References}

1. Filiciotto, L.; Rothenberg, G. Biodegradable Plastics: Standards, Policies, and Impacts. ChemSusChem 2021, 14, 56-72. [CrossRef] [PubMed]

2. Narancic, T.; Cerrone, F.; Beagan, N.; O'Connor, K.E. Recent Advances in Bioplastics: Application and Biodegradation. Polymers 2020, 12, 920. [CrossRef] [PubMed]

3. Zhang, F.; Zhao, Y.; Wang, D.; Yan, M.; Zhang, J.; Zhang, P.; Ding, T.; Chen, L.; Chen, C. Current technologies for plastic waste treatment: A review. J. Clean. Prod. 2021, 282, 124523. [CrossRef]

4. Gigante, V.; Panariello, L.; Coltelli, M.-B.; Danti, S.; Obisesan, K.A.; Hadrich, A.; Staebler, A.; Chierici, S.; Canesi, I.; Lazzeri, A.; et al. Liquid and Solid Functional Bio-Based Coatings. Polymers 2021, 13, 3640. [CrossRef] [PubMed]

5. Nakajima, H.; Dijkstra, P.; Loos, K. The recent developments in biobased polymers toward general and engineering applications: Polymers that are upgraded from biodegradable polymers, analogous to petroleum-derived polymers, and newly developed. Polymers 2017, 9, 523. [CrossRef]

6. Ahn, B.D.; Kim, S.H.; Kim, Y.H.; Yang, J.S. Synthesis and characterization of the biodegradable copolymers from succinic acid and adipic acid with 1,4-butanediol. J. Appl. Polym. Sci. 2001, 82, 2808-2826. [CrossRef]

7. Jabeen, N.; Majid, I.; Nayik, G.A. Bioplastics and food packaging: A review. Cogent Food Agric. 2015, 1, 1117749. [CrossRef]

8. Emadian, S.M.; Onay, T.T.; Demirel, B. Biodegradation of bioplastics in natural environments. Waste Manag. 2017, 59, 526-536. [CrossRef]

9. Narancic, T.; Verstichel, S.; Reddy Chaganti, S.; Morales-Gamez, L.; Kenny, S.T.; De Wilde, B.; Babu Padamati, R.; O'Connor, K.E. Biodegradable Plastic Blends Create New Possibilities for End-of-Life Management of Plastics but They Are Not a Panacea for Plastic Pollution. Environ. Sci. Technol. 2018, 52, 10441-10452. [CrossRef]

10. Gigante, V.; Canesi, I.; Cinelli, P.; Coltelli, M.B.; Lazzeri, A. Rubber Toughening of Polylactic Acid (PLA) with Poly(butylene adipate-co-terephthalate) (PBAT): Mechanical Properties, Fracture Mechanics and Analysis of Ductile-to-Brittle Behavior while Varying Temperature and Test Speed. Eur. Polym. J. 2019, 115, 125-137. [CrossRef]

11. Chen, Y.; Hung, S.-T.; Chou, E.; Wu, H.-S. Review of Polyhydroxyalkanoates Materials and other Biopolymers for Medical Applications. Mini-Rev. Org. Chem. 2018, 15, 105-121. [CrossRef]

12. Cinelli, P.; Mallegni, N.; Gigante, V.; Montanari, A.; Seggiani, M.; Coltelli, M.B.; Bronco, S.; Lazzeri, A. Biocomposites based on polyhydroxyalkanoates and natural fibres from renewable byproducts. Appl. Food Biotechnol. 2019, 6, 35-43. [CrossRef]

13. Coltelli, M.-B.; Gigante, V.; Cinelli, P.; Lazzeri, A. Bionanotechnology to Save the Environment; Morganti, P., Ed.; MDPI: Basel, Switzerland, 2019; ISBN 978-3-03842-693-6.

14. Aliotta, L.; Gigante, V.; Coltelli, M.B.; Cinelli, P.; Lazzeri, A. Evaluation of Mechanical and Interfacial Properties of Bio-Composites Based on Poly (Lactic Acid) with Natural Cellulose Fibers. Int. J. Mol. Sci. 2019, 20, 960. [CrossRef]

15. Coiai, S.; Di Lorenzo, M.L.; Cinelli, P.; Righetti, M.C.; Passaglia, E. Binary Green Blends of Poly(lactic acid) with Poly(butylene adipate-co-butylene terephthalate) and Poly(butylene succinate-co-butylene adipate) and Their Nanocomposites. Polymers 2021, 13, 2489. [CrossRef]

16. Doi, Y.; Steinbüchel, A. Biological Systems and Biotechnological Production. In Biopolymers; Wiley-VCH: Weinheim, Germany, 2001.

17. Puchalski, M.; Szparaga, G.; Biela, T.; Gutowska, A.; Sztajnowski, S.; Krucińska, I. Molecular and supramolecular changes in polybutylene succinate (PBS) and polybutylene succinate adipate (PBSA) copolymer during degradation in various environmental conditions. Polymers 2018, 10, 251. [CrossRef]

18. Díaz, A.; Katsarava, R.; Puiggalí, J. Synthesis, Properties and Applications of Biodegradable Polymers Derived from Diols and Dicarboxylic Acids: From Polyesters to Poly(ester amide)s. Int. J. Mol. Sci. 2014, 15, 7064-7123. [CrossRef]

19. Changwichan, K.; Silalertruksa, T.; Gheewala, S. Eco-Efficiency Assessment of Bioplastics Production Systems and End-of-Life Options. Sustainability 2018, 10, 952. [CrossRef]

20. Bi, S.; Tan, B.; Soule, J.L.; Sobkowicz, M.J. Enzymatic degradation of poly (butylene succinate-co-hexamethylene succinate). Polym. Degrad. Stab. 2018, 155, 9-14. [CrossRef]

21. Safari, M.; Otaegi, I.; Aramburu, N.; Guerrica-Echevarria, G.; de Ilarduya, A.; Sardon, H.; Müller, A. Synthesis, Structure, Crystallization and Mechanical Properties of Isodimorphic PBS-ran-PCL Copolyesters. Polymers 2021, 13, 2263. [CrossRef]

22. Luo, S.; Li, F.; Yu, J.; Cao, A. Synthesis of poly(butylene succinate- co -butylene terephthalate) (PBST) copolyesters with high molecular weights via direct esterification and polycondensation. J. Appl. Polym. Sci. 2010, 115, 2203-2211. [CrossRef]

23. Wu, L.; Mincheva, R.; Xu, Y.; Raquez, J.-M.; Dubois, P. High Molecular Weight Poly(butylene succinate- co -butylene furandicarboxylate) Copolyesters: From Catalyzed Polycondensation Reaction to Thermomechanical Properties. Biomacromolecules 2012, 13, 2973-2981. [CrossRef] [PubMed] 
24. Debuissy, T.; Pollet, E.; Avérous, L. Synthesis and characterization of biobased poly(butylene succinate-ran-butylene adipate). Analysis of the composition-dependent physicochemical properties. Eur. Polym. J. 2017, 87, 84-98. [CrossRef]

25. Binti Ali, F.; Mohan, R. Thermal, Mechanical, and Rheological Properties of Biodegradable Polybutylene Succinate/Carbon Nanotubes. Polym. Compos. 2010, 1309-1314. [CrossRef]

26. Gowman, A.; Wang, T.; Rodriguez-Uribe, A.; Mohanty, A.K.; Misra, M. Bio-poly(butylene succinate) and Its Composites with Grape Pomace: Mechanical Performance and Thermal Properties. ACS Omega 2018, 3, 15205-15216. [CrossRef]

27. Vytejčková, S.; Vápenka, L.; Hradecký, J.; Dobiáš, J.; Hajšlová, J.; Loriot, C.; Vannini, L.; Poustka, J. Testing of polybutylene succinate based films for poultry meat packaging. Polym. Test. 2017, 60, 357-364. [CrossRef]

28. Aziman, N.; Kian, L.K.; Jawaid, M.; Sanny, M.; Alamery, S. Morphological, Structural, Thermal, Permeability, and Antimicrobial Activity of PBS and PBS/TPS Films Incorporated with Biomaster-Silver for Food Packaging Application. Polymers 2021, 13, 391. [CrossRef]

29. Coltelli, M.; Aliotta, L.; Gigante, V.; Bellusci, M.; Cinelli, P.; Bugnicourt, E.; Schmid, M.; Staebler, A.; Lazzeri, A. Preparation and Compatibilization of PBS/Whey Protein Isolate Based Blends. Molecules 2020, 25, 3313. [CrossRef]

30. Thirmizir, M.Z.A.; Ishak, Z.A.M.; Taib, R.M.; Pillai, K.S.K.C.K.; Salim, M.S.; Hassan, A.; Abu Bakar, M.B. The effects of melt grafted maleated polybutylene succinate on the properties of poly(hydroxybutyrate-co-hydroxyhexanoate)/polybutylene succinate blends. J. Vinyl Addit. Technol. 2021, 27, 567-588. [CrossRef]

31. Ku-Marsilla, K.I.; Verbeek, C.J.R. Compatibilization of Protein Thermoplastics and Polybutylene Succinate Blends. Macromol. Mater. Eng. 2015, 300, 161-171. [CrossRef]

32. Yokohara, T.; Yamaguchi, M. Structure and properties for biomass-based polyester blends of PLA and PBS. Eur. Polym. J. 2008, 44, 677-685. [CrossRef]

33. Altieri, R.; Seggiani, M.; Esposito, A.; Cinelli, P.; Stanzione, V. Thermoplastic Blends Based on Poly(Butylene Succinate-co-Adipate) and Different Collagen Hydrolysates from Tanning Industry-II: Aerobic Biodegradation in Composting Medium. J. Polym. Environ. 2021, 29, 3375-3388. [CrossRef]

34. Siwek, P.; Libik, A.; Kalisz, A.; Zawiska, I. The effect of biodegradable nonwoven direct covers on yield and quality of winter leek. Folia Hortic. 2013, 25, 61-65. [CrossRef]

35. Balestri, E.; Vallerini, F.; Seggiani, M.; Cinelli, P.; Menicagli, V.; Vannini, C.; Lardicci, C. Use of bio-containers from seagrass wrack with nursery planting to improve the eco-sustainability of coastal habitat restoration. J. Environ. Manag. 2019, 251, 109604. [CrossRef]

36. Bautista, M.; Martínez de Ilarduya, A.; Alla, A.; Vives, M.; Morató, J.; Muñoz-Guerra, S. Cationic poly(butylene succinate) copolyesters. Eur. Polym. J. 2016, 75, 329-342. [CrossRef]

37. Thurber, H.; Curtzwiler, G.W. Suitability of poly(butylene succinate) as a coating for paperboard convenience food packaging. Int. J. Biobased Plast. 2020, 2, 1-12. [CrossRef]

38. Su, S.; Kopitzky, R.; Tolga, S.; Kabasci, S. Polylactide (PLA) and Its Blends with Poly(butylene succinate) (PBS): A Brief Review. Polymers 2019, 11, 1193. [CrossRef]

39. Soroudi, A.; Jakubowicz, I. Recycling of bioplastics, their blends and biocomposites: A review. Eur. Polym. J. 2013, 49, 2839-2858. [CrossRef]

40. Fortunati, E.; Puglia, D.; Iannoni, A.; Terenzi, A.; Kenny, J.M.; Torre, L. Processing conditions, thermal and mechanical responses of stretchable poly (lactic acid)/poly (butylene succinate) films. Materials 2017, 10, 809. [CrossRef]

41. Shelley, T. Eureka: Plastics get greener. Cell. Polym. 2011, 30, 40-42.

42. Aversa, C.; Barletta, M.; Puopolo, M.; Vesco, S. Cast extrusion of low gas permeability bioplastic sheets in PLA/PBS and PLA/PHB binary blends. Polym. Technol. Mater. 2020, 59, 231-240. [CrossRef]

43. Xu, J.; Guo, B. Poly(butylene succinate) and its copolymers: Research, development and industrialization. Biotechnol. J. 2010, 5, 1149-1163. [CrossRef]

44. Tserki, V.; Matzinos, P.; Pavlidou, E.; Vachliotis, D.; Panayiotou, C. Biodegradable aliphatic polyesters. Part I. Properties and biodegradation of poly(butylene succinate-co-butylene adipate). Polym. Degrad. Stab. 2006, 91, 367-376. [CrossRef]

45. Tserki, V.; Matzinos, P.; Pavlidou, E.; Panayiotou, C. Biodegradable aliphatic polyesters. Part II. Synthesis and characterization of chain extended poly(butylene succinate-co-butylene adipate). Polym. Degrad. Stab. 2006, 91, 377-384. [CrossRef]

46. Sugihara, S.; Toshima, K.; Matsumura, S. New Strategy for Enzymatic Synthesis of High-Molecular-Weight Poly(butylene succinate) via Cyclic Oligomers. Macromol. Rapid Commun. 2006, 27, 203-207. [CrossRef]

47. Takiyama, E.; Fujimaki, T.; Seki, S.; Hokari, T.; Hatano, Y. Method for Manufacturing Biodegradable High Molecular Aliphatic Polyester. U.S. Patent 5,310,782, 10 May 1994.

48. Xu, J.; Guo, B.-H. Microbial Succinic Acid, Its Polymer Poly(butylene succinate), and Applications. In Plastics from Bacteria; Springer: Berlin/Heidelberg, Germany, 2010; pp. 347-388.

49. Jacquel, N.; Freyermouth, F.; Fenouillot, F.; Rousseau, A.; Pascault, J.P.; Fuertes, P.; Saint-Loup, R. Synthesis and properties of poly(butylene succinate): Efficiency of different transesterification catalysts. J. Polym. Sci. Part A Polym. Chem. 2011, 49, 5301-5312. [CrossRef]

50. Ravichandran, R.; Sundarrajan, S.; Venugopal, J.R.; Mukherjee, S.; Ramakrishna, S. Advances in Polymeric Systems for Tissue Engineering and Biomedical Applications. Macromol. Biosci. 2012, 12, 286-311. [CrossRef] [PubMed] 
51. Wang, C.; Ming, W.; Yan, D.; Zhang, C.; Yang, M.; Liu, Y.; Zhang, Y.; Guo, B.; Wan, Y.; Xing, J. Novel membrane-based biotechnological alternative process for succinic acid production and chemical synthesis of bio-based poly (butylene succinate). Bioresour. Technol. 2014, 156, 6-13. [CrossRef] [PubMed]

52. Sharma, R.; Singh, J.; Verma, N. Optimization of rhamnolipid production from Pseudomonas aeruginosa PBS towards application for microbial enhanced oil recovery. 3 Biotech 2018, 8, 20. [CrossRef] [PubMed]

53. Datta, J.; Głowińska, E. Effect of hydroxylated soybean oil and bio-based propanediol on the structure and thermal properties of synthesized bio-polyurethanes. Ind. Crops Prod. 2014, 61, 84-91. [CrossRef]

54. Sisti, L.; Totaro, G.; Marchese, P. PBS Makes Its Entrance into the Family of Biobased Plastics; John Wiley \& Sons: Hoboken, NJ, USA, 2016.

55. Altstadt, E.; Serrano, M.; Houska, M.; García-Junceda, A.; Aeschelmann, F.; Carus, M.; Baltus, W.; Jacquel, N.; Saint-Loup, R.; Pascault, J.-P.; et al. Bio-based building blocks and polymers in the world: Capacities, production, and applications-status quo and trends towards 2020. Ind. Biotechnol. 2015, 11, 154-159. [CrossRef]

56. Sanford, K.; Chotani, G.; Danielson, N.; Zahn, J.A. Scaling up of renewable chemicals. Curr. Opin. Biotechnol. 2016, 38, 112-122. [CrossRef]

57. RameshKumar, S.; Shaiju, P.; O'Connor, K.E. Bio-based and biodegradable polymers-State-of-the-art, challenges and emerging trends. Curr. Opin. Green Sustain. Chem. 2020, 21, 75-81. [CrossRef]

58. Muthuraj, R.; Misra, M.; Mohanty, A.K. Binary blends of poly(butylene adipate-co-Terephthalate) and poly(butylene succinate): A new matrix for biocomposites applications. AIP Conf. Proc. 2015, 1664, 150009. [CrossRef]

59. Barletta, M.; Puopolo, M. Thermoforming of compostable PLA/PBS blends reinforced with highly hygroscopic calcium carbonate. J. Manuf. Process. 2020, 56, 1185-1192. [CrossRef]

60. Zhan, J.; Chen, Y.; Tang, G.; Pan, H.; Zhang, Q.; Song, L.; Hu, Y. Crystallization and melting properties of poly(butylene succinate) composites with titanium dioxide nanotubes or hydroxyapatite nanorods. J. Appl. Polym. Sci. 2014, 131, 1-10. [CrossRef]

61. Righetti, M.C.; Cinelli, P.; Aliotta, L.; Bianchi, E.; Tricoli, F.; Seggiani, M.; Lazzeri, A. Immiscible PHB/PBS and PHB/PBSA blends: Morphology, phase composition and modelling of elastic modulus. Polym. Int. 2022, 71, 47-56. [CrossRef]

62. Wang, X.; Zhou, J.; Li, L. Multiple melting behavior of poly(butylene succinate). Eur. Polym. J. 2007, 43, 3163-3170. [CrossRef]

63. Ihn, K.J.; Yoo, E.S.; Im, S.S. Structure and Morphology of Poly(tetramethylene succinate) Crystals. Macromolecules 1995, 28, 2460-2464. [CrossRef]

64. Ichikawa, Y.; Suzuki, J.; Washiyama, J.; Moteki, Y.; Noguchi, K.; Okuyama, K. Strain-induced crystal modification in poly(tetramethylene succinate). Polymer 1994, 35, 3338-3339. [CrossRef]

65. Horii, F.; Hirai, A.; Murayama, K.; Kitamaru, R.; Suzuki, T. Molecular mobilities of individual constituent carbons of solid polyesters above $\mathrm{Tg}$ as studied by carbon-13 nuclear magnetic resonance spectroscopy. Macromolecules 1983, 16, $273-278$. [CrossRef]

66. Kuwabara, K.; Gan, Z.; Nakamura, T.; Abe, H.; Doi, Y. Temperature dependence of the molecular motion in the crystalline region of biodegradable poly(butylene adipate), poly(ethylene succinate), and poly(butylene succinate). Polym. Degrad. Stab. 2004, 84, 105-114. [CrossRef]

67. Ichikawa, Y.; Kondo, H.; Igarashi, Y.; Noguchi, K.; Okuyama, K.; Washiyama, J. Crystal structures of $\alpha$ and $\beta$ forms of poly(tetramethylene succinate). Polymer 2000, 41, 4719-4727. [CrossRef]

68. Yoo, E.S.; Im, S.S. Melting behavior of poly(butylene succinate) during heating scan by DSC. J. Polym. Sci. Part B Polym. Phys. 1999, 37, 1357-1366. [CrossRef]

69. Wang, Z.-G.; Hsiao, B.S.; Murthy, N.S. Comparison of intensity profile analysis and correlation function methods for studying the lamellar structures of semi-crystalline polymers using small-angle X-ray scattering. J. Appl. Crystallogr. 2000, 33, 690-694. [CrossRef]

70. Liu, T.; Petermann, J.; He, C.; Liu, Z.; Chung, T.-S. Transmission Electron Microscopy Observations on Lamellar Melting of Cold-Crystallized Isotactic Polystyrene. Macromolecules 2001, 34, 4305-4307. [CrossRef]

71. Al-Hussein, M.; Strobl, G. The Melting Line, the Crystallization Line, and the Equilibrium Melting Temperature of Isotactic Polystyrene. Macromolecules 2002, 35, 1672-1676. [CrossRef]

72. Schwarz, I.; Stranz, M.; Bonnet, M.; Petermann, J. Changes of mechanical properties in cold-crystallized syndiotactic polypropylene during aging. Colloid Polym. Sci. 2001, 279, 506-512. [CrossRef]

73. Shafee, E.E. Effect of aging on the mechanical properties of cold-crystallized poly(trimethylene terephthalate). Polymer 2003, 44, 3727-3732. [CrossRef]

74. Nikolic, M.S.; Djonlagic, J. Synthesis and characterization of biodegradable poly(butylene succinate-co-butylene adipate)s. Polym. Degrad. Stab. 2001, 74, 263-270. [CrossRef]

75. Han, Y.-K.; Kim, S.-R.; Kim, J. Preparation and characterization of high molecular weight poly(butylene succinate). Macromol. Res. 2002, 10, 108-114. [CrossRef]

76. Nagata, M. Synthesis and enzymatic degradation of poly(tetramethylene succinate) copolymers with terephthalic acid. Polymer 2000, 41, 4373-4376. [CrossRef]

77. Li, F.; Xu, X.; Li, Q.; Li, Y.; Zhang, H.; Yu, J.; Cao, A. Thermal degradation and their kinetics of biodegradable poly(butylene succinate-co-butylene terephthate)s under nitrogen and air atmospheres. Polym. Degrad. Stab. 2006, 91, 1685-1693. [CrossRef] 
78. Takasu, A.; Oishi, Y.; Iio, Y.; Inai, Y.; Hirabayashi, T. Synthesis of Aliphatic Polyesters by Direct Polyesterification of Dicarboxylic Acids with Diols under Mild Conditions Catalyzed by Reusable Rare-Earth Triflate. Macromolecules 2003, 36, 1772-1774. [CrossRef]

79. Chae, H.G.; Park, S.H.; Kim, B.C.; Kim, D.K. Effect of methyl substitution of the ethylene unit on the physical properties of poly(butylene succinate). J. Polym. Sci. Part B Polym. Phys. 2004, 42, 1759-1766. [CrossRef]

80. Sun, Y.; Xu, J.; Xu, Y.; Guo, B. Synthesis and crystallization behavior of biodegradable poly(butylene succinate-co-butylene phenylsuccinate). Acta Polym. Sin. 2010, 6, 745-749. [CrossRef]

81. Mochizuki, M.; Mukai, K.; Yamada, K.; Ichise, N.; Murase, S.; Iwaya, Y. Structural Effects upon Enzymatic Hydrolysis of Poly(butylene succinate- co -ethylene succinate)s. Macromolecules 1997, 30, 7403-7407. [CrossRef]

82. Cao, A.; Okamura, T.; Nakayama, K.; Inoue, Y.; Masuda, T. Studies on syntheses and physical properties of biodegradable aliphatic poly(butylene succinate-co-ethylene succinate)s and poly(butylene succinate-co-diethylene glycol succinate)s. Polym. Degrad. Stab. 2002, 78, 107-117. [CrossRef]

83. Deng, L.-M.; Wang, Y.-Z.; Yang, K.-K.; Wang, X.-L.; Zhou, Q.; Ding, S.-D. A new biodegradable copolyester poly(butylene succinate-co-ethylene succinate-co-ethylene terephthalate). Acta Mater. 2004, 52, 5871-5878. [CrossRef]

84. Arandia, I.; Mugica, A.; Zubitur, M.; Arbe, A.; Liu, G.; Wang, D.; Mincheva, R.; Dubois, P.; Müller, A.J. How composition determines the properties of isodimorphic poly(butylene succinate- ran -butylene azelate) random biobased copolymers: From single to double crystalline random copolymers. Macromolecules 2015, 48, 43-57. [CrossRef]

85. Pan, P.; Inoue, Y. Polymorphism and isomorphism in biodegradable polyesters. Prog. Polym. Sci. 2009, 34, 605-640. [CrossRef]

86. Pérez-Camargo, R.A.; Fernández-D’Arlas, B.; Cavallo, D.; Debuissy, T.; Pollet, E.; Avérous, L.; Müller, A.J. Tailoring the structure, morphology, and crystallization of isodimorphic poly(butylene succinate-ran-butylene adipate) random copolymers by changing composition and thermal history. Macromolecules 2017, 50, 597-608. [CrossRef]

87. Chen, C.-H.; Yang, C.-S.; Chen, M.; Shih, Y.-C.; Hsu, H.-S.; Lu, S.-F. Synthesis and characterization of novel poly(butylene succinate-co-2-methyl-1,3-propylene succinate)s. Express Polym. Lett. 2011, 5, 284-294. [CrossRef]

88. Peng, S.; Bu, Z.; Wu, L.; Li, B.G.; Dubois, P. High molecular weight poly(butylene succinate-co-furandicarboxylate) with 10 mol\% of BF unit: Synthesis, crystallization-melting behavior and mechanical properties. Eur. Polym. J. 2017, 96, 248-255. [CrossRef]

89. Aliotta, L.; Gigante, V.; Coltelli, M.-B.; Lazzeri, A. Volume Change during Creep and Micromechanical Deformation Processes in PLA-PBSA Binary Blends. Polymers 2021, 13, 2379. [CrossRef] [PubMed]

90. Chen, G.X.; Yoon, J.S. Thermal stability of poly(l-lactide)/poly(butylene succinate)/clay nanocomposites. Polym. Degrad. Stab. 2005, 88, 206-212. [CrossRef]

91. Homklin, R.; Hongsriphan, N.; Phetwarotai, W.; Aht-Ong, D.; Suksut, B.; Deeprasertkul, C.; Leong, Y.W.; Ishak, Z.A.M.; Ariffin, A.; Homklin, R.; et al. Mechanical and thermal properties of PLA/PBS co-continuous blends adding nucleating agent. Energy Procedia 2013, 34, 871-879. [CrossRef]

92. Liu, L.; Yu, J.; Cheng, L.; Qu, W. Mechanical properties of poly (butylene succinate)(PBS) biocomposites reinforced with surface modified jute fibre. Compos. Part A Appl. Sci. Manuf. 2009, 40, 669-674. [CrossRef]

93. Wang, R.; Wang, S.; Zhang, Y.; Wan, C.; Ma, P. Toughening modification of PLLA/PBS blends via in situ compatibilization. Polym. Eng. Sci. 2009, 49, 26-33. [CrossRef]

94. Gigante, V.; Coltelli, M.-B.; Vannozzi, A.; Panariello, L.; Fusco, A.; Trombi, L.; Donnarumma, G.; Danti, S.; Lazzeri, A. Flat Die Extruded Biocompatible Poly(Lactic Acid) (PLA)/Poly(Butylene Succinate) (PBS) Based Films. Polymers 2019, 11, 1857. [CrossRef]

95. Aliotta, L.; Vannozzi, A.; Panariello, L.; Gigante, V.; Coltelli, M.B.; Lazzeri, A. Sustainable Micro and Nano Additives for Controlling the Migration of a Biobased Plasticizer from PLA-Based Flexible Films. Polymers 2020, 12, 1366. [CrossRef]

96. Coltelli, M.-B.; Aliotta, L.; Vannozzi, A.; Morganti, P.; Panariello, L.; Danti, S.; Neri, S.; Fernandez-Avila, C.; Fusco, A.; Donnarumma, G.; et al. Properties and Skin Compatibility of Films Based on Poly(Lactic Acid) (PLA) Bionanocomposites Incorporating Chitin Nanofibrils (CN). J. Funct. Biomater. 2020, 11, 21. [CrossRef]

97. Ojijo, V.; Sinha Ray, S.; Sadiku, R. Role of specific interfacial area in controlling properties of immiscible blends of biodegradable polylactide and poly[(butylene succinate)-co-adipate]. ACS Appl. Mater. Interfaces 2012, 4, 6690-6701. [CrossRef]

98. Messin, T.; Marais, S.; Follain, N.; Guinault, A.; Gaucher, V.; Delpouve, N.; Sollogoub, C. Biodegradable PLA/PBS multinanolayer membrane with enhanced barrier performances. J. Membr. Sci. 2020, 598, 117777. [CrossRef]

99. Ma, P.; Hristova-Bogaerds, D.G.; Lemstra, P.J.; Zhang, Y.; Wang, S. Toughening of PHBV/PBS and PHB/PBS blends via in situ compatibilization using dicumyl peroxide as a free-radical grafting initiator. Macromol. Mater. Eng. 2012, 297, 402-410. [CrossRef]

100. Zeng, J.-B.; Jiao, L.; Li, Y.-D.; Srinivasan, M.; Li, T.; Wang, Y.-Z. Bio-based blends of starch and poly(butylene succinate) with improved miscibility, mechanical properties, and reduced water absorption. Carbohydr. Polym. 2011, 83, 762-768. [CrossRef]

101. Seggiani, M.; Gigante, V.; Cinelli, P.; Coltelli, M.B.; Sandroni, M.; Anguillesi, I.; Lazzeri, A. Processing and mechanical performances of Poly(Butylene Succinate-co-Adipate)(PBSA)and raw hydrolyzed collagen (HC)thermoplastic blends. Polym. Test. 2019, 77, 105900. [CrossRef]

102. La Mantia, F.P.; Morreale, M. Green composites: A brief review. Compos. Part A Appl. Sci. Manuf. 2011, 42, 579-588. [CrossRef]

103. Lim, S.T.; Hyun, Y.H.; Choi, H.J.; Jhon, M.S. Synthetic biodegradable aliphatic polyester/montmorillonite nanocomposites. Chem. Mater. 2002, 14, 1839-1844. [CrossRef]

104. Fujimaki, T. Processability and properties of aliphatic polyesters, 'BIONOLLE', synthesized by polycondensation reaction. Polym. Degrad. Stab. 1998, 59, 209-214. [CrossRef] 
105. Ijeri, V.S.; Nair, J.R.; Gerbaldi, C.; Gonnelli, R.S.; Bodoardo, S.; Bongiovanni, R.M. An elegant and facile single-step UV-curing approach to surface nano-silvering of polymer composites. Soft Matter 2010, 6, 4666-4668. [CrossRef]

106. Wallace, G.G.; Teasdale, P.R.; Spinks, G.M.; Kane-Maguire, L.A.P. Conductive Electroactive Polymers; CRC Press: Boca Raton, FL, USA, 2008; ISBN 9780429145339.

107. Shamsuri, A.A.; Md. Jamil, S.N.A.; Abdan, K. A Brief Review on the Influence of Ionic Liquids on the Mechanical, Thermal, and Chemical Properties of Biodegradable Polymer Composites. Polymers 2021, 13, 2597. [CrossRef]

108. Sivanjineyulu, V.; Behera, K.; Chang, Y.-H.; Chiu, F.-C. Selective localization of carbon nanotube and organoclay in biodegradable poly(butylene succinate)/polylactide blend-based nanocomposites with enhanced rigidity, toughness and electrical conductivity. Compos. Part A Appl. Sci. Manuf. 2018, 114, 30-39. [CrossRef]

109. Gumyusenge, A.; Tran, D.T.; Luo, X.; Pitch, G.M.; Zhao, Y.; Jenkins, K.A.; Dunn, T.J.; Ayzner, A.L.; Savoie, B.M.; Mei, J. Semiconducting polymer blends that exhibit stable charge transport at high temperatures. Science 2018, 362, 1131-1134. [CrossRef]

110. José-Yacamán, M.; Miki-Yoshida, M.; Rendón, L.; Santiesteban, J.G. Catalytic growth of carbon microtubules with fullerene structure. Appl. Phys. Lett. 1993, 62, 657-659. [CrossRef]

111. Yarici, T.; Kodal, M.; Ozkoc, G. Non-isothermal crystallization kinetics of Poly(Butylene succinate) (PBS) nanocomposites with different modified carbon nanotubes. Polymer 2018, 146, 361-377. [CrossRef]

112. Ray, S.S.; Vaudreuil, S.; Maazouz, A.; Bousmina, M. Dispersion of Multi-Walled Carbon Nanotubes in Biodegradable Poly(butylene succinate) Matrix. J. Nanosci. Nanotechnol. 2006, 6, 2191-2195. [CrossRef]

113. Hsieh, H.-C.; Wu, N.; Chuang, T.-H.; Lee, W.-Y.; Chen, J.-Y.; Chen, W.-C. Eco-Friendly Polyfluorene/Poly(butylene succinate) Blends and Their Electronic Device Application on Biodegradable Substrates. ACS Appl. Polym. Mater. 2020, 2, $2469-2476$. [CrossRef]

114. Biswas, M.; Ray, S.S. Recent Progress in Synthesis and Evaluation of Polymer-Montmorillonite Nanocomposites. Adv. Polym. Sci. 2001, 155, 167-221.

115. Giannelis, E.P. Polymer-layered silicate nanocomposites: Synthesis, properties and applications. Appl. Organomet. Chem. 1998, 12, 675-680. [CrossRef]

116. Sinha Ray, S.; Okamoto, K.; Okamoto, M. Structure-Property Relationship in Biodegradable Poly(butylene succinate)/Layered Silicate Nanocomposites. Macromolecules 2003, 36, 2355-2367. [CrossRef]

117. Ray, S.S.; Bandyopadhyay, J.; Bousmina, M. Thermal and thermomechanical properties of poly[(butylene succinate)-co-adipate] nanocomposite. Polym. Degrad. Stab. 2007, 92, 802-812. [CrossRef]

118. Chen, C.-H. Effect of attapulgite on the crystallization behavior and mechanical properties of poly(butylene succinate) nanocomposites. J. Phys. Chem. Solids 2008, 69, 1411-1414. [CrossRef]

119. Sinha Ray, S.; Okamoto, K.; Maiti, P.; Okamoto, M. New Poly(butylene succinate)/Layered Silicate Nanocomposites: Preparation and Mechanical Properties. J. Nanosci. Nanotechnol. 2002, 2, 171-176. [CrossRef]

120. Chieng, B.W.; Ibrahim, N.A.; Wan Yunus, W.M.Z. Effect of organo-modified montmorillonite on poly(butylene succinate)/poly(butylene adipate-co-terephthalate) nanocomposites. Express Polym. Lett. 2010, 4, 404-414. [CrossRef]

121. Bhatia, A.; Gupta, R.K.; Bhattacharya, S.N.; Choi, H.J. Effect of Clay on Thermal, Mechanical and Gas Barrier Properties of Biodegradable Poly(lactic acid)/Poly(butylene succinate) (PLA/PBS) Nanocomposites. Int. Polym. Process. 2010, 25, 5-14. [CrossRef]

122. Mohanty, A.K.; Misra, M.; Hinrichsen, G. Biofibres, biodegradable polymers and biocomposites: An overview. Macromol. Mater. Eng. 2000, 276-277, 1-24. [CrossRef]

123. Mwaikambo, L.Y.; Ansell, M.P. The effect of chemical treatment on the properties of hemp, sisal, jute and kapok for composite reinforcement. Die Angew. Makromol. Chem. 1999, 272, 108-116. [CrossRef]

124. Dorez, G.; Taguet, A.; Ferry, L.; Lopez-Cuesta, J.M. Thermal and fire behavior of natural fibers/PBS biocomposites. Polym. Degrad. Stab. 2013, 98, 87-95. [CrossRef]

125. Phiriyawirut, M.; Mekaroonluck, J.; Hauyam, T.; Kittilaksanon, A. Biomass-Based Foam from Crosslinked Tapioca Starch/ Polybutylene Succinate Blend. J. Renew. Mater. 2016, 4, 185-189. [CrossRef]

126. Zhao, Y.; Qiu, J.; Feng, H.; Zhang, M. The interfacial modification of rice straw fiber reinforced poly(butylene succinate) composites: Effect of aminosilane with different alkoxy groups. J. Appl. Polym. Sci. 2012, 125, 3211-3220. [CrossRef]

127. Sangilimuthukumar, J.; Kumar, T.S.M.; Santulli, C.; Chandrasekar, M.; Senthilkumar, K.; Siengchin, S. The Use of Pineapple Fiber Composites for Automotive Applications: A Short Review. J. Mater. Sci. Res. Rev. 2020, 6, 39-45.

128. Lee, S.-H.; Wang, S. Biodegradable polymers/bamboo fiber biocomposite with bio-based coupling agent. Compos. Part A Appl. Sci. Manuf. 2006, 37, 80-91. [CrossRef]

129. Terzopoulou, Z.N.; Papageorgiou, G.Z.; Papadopoulou, E.; Athanassiadou, E.; Reinders, M.; Bikiaris, D.N. Development and study of fully biodegradable composite materials based on poly(butylene succinate) and hemp fibers or hemp shives. Polym. Compos. 2016, 37, 407-421. [CrossRef]

130. Calabia, B.P.; Ninomiya, F.; Yagi, H.; Oishi, A.; Taguchi, K.; Kunioka, M.; Funabashi, M. Biodegradable poly (butylene succinate) composites reinforced by cotton fiber with silane coupling agent. Polymers 2013, 5, 128-141. [CrossRef]

131. Zhu, N.; Ye, M.; Shi, D.; Chen, M. Reactive compatibilization of biodegradable poly(butylene succinate)/Spirulina microalgae composites. Macromol. Res. 2017, 25, 165-171. [CrossRef] 
132. Lee, S.M.; Cho, D.; Park, W.H.; Lee, S.G.; Han, S.O.; Drzal, L.T. Novel silk/poly(butylene succinate) biocomposites: The effect of short fibre content on their mechanical and thermal properties. Compos. Sci. Technol. 2005, 65, 647-657. [CrossRef]

133. Aliotta, L.; Lazzeri, A. A proposal to modify the Kelly-Tyson equation to calculate the interfacial shear strength (IFSS) of composites with low aspect ratio fibers. Compos. Sci. Technol. 2020, 186, 107920. [CrossRef]

134. Frollini, E.; Bartolucci, N.; Sisti, L.; Celli, A. Biocomposites based on poly(butylene succinate) and curaua: Mechanical and morphological properties. Polym. Test. 2015, 45, 168-173. [CrossRef]

135. Cinelli, P.; Seggiani, M.; Mallegni, N.; Gigante, V.; Lazzeri, A. Processability and Degradability of PHA-Based Composites in Terrestrial Environments. Int. J. Mol. Sci. 2019, 20, 284. [CrossRef]

136. Pandey, J.K.; Nagarajan, V.; Mohanty, A.K.; Misra, M. 1-Commercial potential and competitiveness of natural fiber composites. In Woodhead Publishing Series in Composites Science and Engineering; Misra, M., Pandey, J.K., Mohanty, A.K.B.T.-B., Eds.; Woodhead Publishing: Cambridge, UK, 2015; pp. 1-15, ISBN 978-1-78242-373-7.

137. da Silva, D.; Kaduri, M.; Poley, M.; Adir, O.; Krinsky, N.; Shainsky-Roitman, J.; Schroeder, A. Biocompatibility, biodegradation and excretion of polylactic acid (PLA) in medical implants and theranostic systems. Chem. Eng. J. 2018, 340, 9-14. [CrossRef]

138. Vert, M.; Santos, I.D.; Ponsart, S.; Alauzet, N.; Morgat, J.-L.; Coudane, J.; Garreau, H. Degradable polymers in a living environment: Where do you end up? Polym. Int. 2002, 51, 840-844. [CrossRef]

139. Kanemura, C.; Nakashima, S.; Hotta, A. Mechanical properties and chemical structures of biodegradable poly(butylene-succinate) for material reprocessing. Polym. Degrad. Stab. 2012, 97, 972-980. [CrossRef]

140. Aliotta, L.; Vannozzi, A.; Canesi, I.; Cinelli, P.; Coltelli, M.; Lazzeri, A. Poly(lactic acid) (PLA)/Poly(butylene succinate-coadipate) (PBSA) Compatibilized Binary Biobased Blends: Melt Fluidity, Morphological, Thermo-Mechanical and Micromechanical Analysis. Polymers 2021, 13, 218. [CrossRef]

141. Phua, Y.J.; Lau, N.S.; Sudesh, K.; Chow, W.S.; Mohd Ishak, Z.A. Biodegradability studies of poly(butylene succinate)/organomontmorillonite nanocomposites under controlled compost soil conditions: Effects of clay loading and compatibiliser. Polym. Degrad. Stab. 2012, 97, 1345-1354. [CrossRef]

142. Liu, L.; Yu, J.; Cheng, L.; Yang, X. Biodegradability of poly(butylene succinate) (PBS) composite reinforced with jute fibre. Polym. Degrad. Stab. 2009, 94, 90-94. [CrossRef]

143. Zhao, J.H.; Wang, X.Q.; Zeng, J.; Yang, G.; Shi, F.H.; Yan, Q. Biodegradation of poly(butylene succinate) in compost. J. Appl. Polym. Sci. 2005, 97, 2273-2278. [CrossRef]

144. Jacquel, N.; Saint-Loup, R.; Pascault, J.-P.; Rousseau, A.; Fenouillot, F. Bio-based alternatives in the synthesis of aliphatic-aromatic polyesters dedicated to biodegradable film applications. Polymer 2015, 59, 234-242. [CrossRef]

145. Rafiqah, S.A.; Khalina, A.; Harmaen, A.S.; Tawakkal, I.A.; Zaman, K.; Asim, M.; Nurrazi, M.N.; Lee, C.H. A Review on Properties and Application of Bio-Based Poly(Butylene Succinate). Polymers 2021, 13, 1436. [CrossRef]

146. Koitabashi, M.; Noguchi, M.T.; Sameshima-Yamashita, Y.; Hiradate, S.; Suzuki, K.; Yoshida, S.; Watanabe, T.; Shinozaki, Y.; Tsushima, S.; Kitamoto, H.K. Degradation of biodegradable plastic mulch films in soil environment by phylloplane fungi isolated from gramineous plants. AMB Express 2012, 2, 40. [CrossRef]

147. Ayu, R.S.; Khalina, A.; Harmaen, A.S.; Zaman, K.; Mohd Nurrazi, N.; Isma, T.; Lee, C.H. Effect of Empty Fruit Brunch reinforcement in PolyButylene-Succinate/Modified Tapioca Starch blend for Agricultural Mulch Films. Sci. Rep. 2020, 10, 1166. [CrossRef]

148. Guidotti, G.; Soccio, M.; Siracusa, V.; Gazzano, M.; Salatelli, E.; Munari, A.; Lotti, N. Novel Random PBS-Based Copolymers Containing Aliphatic Side Chains for Sustainable Flexible Food Packaging. Polymers 2017, 9, 724. [CrossRef] [PubMed]

149. Pivsa-Art, W.; Chaiyasat, A.; Pivsa-Art, S.; Yamane, H.; Ohara, H. Preparation of Polymer Blends between Poly(Lactic Acid) and Poly(Butylene adipate-co-terephthalate) and Biodegradable Polymers as Compatibilizers. Energy Procedia 2013, 34, 549-554. [CrossRef]

150. Reichert, C.L.; Bugnicourt, E.; Coltelli, M.; Cinelli, P.; Lazzeri, A.; Canesi, I.; Braca, F.; Martínez, B.M.; Alonso, R.; Agostinis, L.; et al. Bio-Based Packaging: Materials, Modifications, Industrial Applications and Sustainability. Polymers 2020, $12,1558$. [CrossRef] [PubMed]

151. Brunner, C.T.; Baran, E.T.; Pinho, E.D.; Reis, R.L.; Neves, N.M. Performance of biodegradable microcapsules of poly(butylene succinate), poly(butylene succinate-co-adipate) and poly(butylene terephthalate-co-adipate) as drug encapsulation systems. Colloids Surf. B Biointerfaces 2011, 84, 498-507. [CrossRef] [PubMed]

152. Babu, R.P.; O'Connor, K.; Seeram, R. Current progress on bio-based polymers and their future trends. Prog. Biomater. $2013,2,8$. [CrossRef] [PubMed]

153. Barletta, M.; Aversa, C.; Puopolo, M.; Donninelli, A. Effect of micro-lamellar talc on dimensional accuracy and stability in injection molding of PLA/PBSA blends. Polym. Technol. Mater. 2019, 58, 776-788. [CrossRef]

154. Azhar, S.W.; Xu, F.; Zhang, Y.; Qiu, Y. Fabrication and mechanical properties of flaxseed fiber bundle-reinforced polybutylene succinate composites. J. Ind. Text. 2019, 50, 98-113. [CrossRef]

155. Kennouche, S.; Le Moigne, N.; Kaci, M.; Quantin, J.C.; Caro-Bretelle, A.S.; Delaite, C.; Lopez-Cuesta, J.M. Morphological characterization and thermal properties of compatibilized poly(3-hydroxybutyrate-co-3-hydroxyvalerate) (PHBV)/poly(butylene succinate) (PBS)/halloysite ternary nanocomposites. Eur. Polym. J. 2016, 75, 142-162. [CrossRef]

156. Mallegni, N.; Phuong, T.V.; Coltelli, M.-B.; Cinelli, P.; Lazzeri, A. Poly(lactic acid) (PLA) based tear resistant and biodegradable flexible films by blown film extrusion. Materials 2018, 11, 148. [CrossRef] 
157. Siracusa, V.; Lotti, N.; Munari, A.; Dalla Rosa, M. Poly(butylene succinate) and poly(butylene succinate-co-adipate) for food packaging applications: Gas barrier properties after stressed treatments. Polym. Degrad. Stab. 2015, 119, 35-45. [CrossRef]

158. Mochane, M.J.; Magagula, S.I.; Sefadi, J.S.; Mokhena, T.C. A Review on Green Composites Based on Natural Fiber-Reinforced Polybutylene Succinate (PBS). Polymers 2021, 13, 1200. [CrossRef] 